Article

\title{
Shaping a Circular Economy in the Digital TV Industry: Focusing on Ecopreneurship through the Lens of Dynamic Capability
}

\author{
Seungyeon Moon (D) and Heesang Lee * (D) \\ Graduate School of Management of Technology, Sungkyunkwan University, Suwon 16419, Korea; \\ symoon@skku.edu \\ * Correspondence: leehee@skku.edu
}

check for updates

Citation: Moon, S.; Lee, H. Shaping a Circular Economy in the Digital TV Industry: Focusing on Ecopreneurship through the Lens of Dynamic Capability. Sustainability 2021, 13, 4865. https://doi.org/ $10.3390 /$ su13094865

Academic Editor: Knut Blind

Received: 5 February 2021

Accepted: 22 April 2021

Published: 26 April 2021

Publisher's Note: MDPI stays neutral with regard to jurisdictional claims in published maps and institutional affiliations.

Copyright: (c) 2021 by the authors. Licensee MDPI, Basel, Switzerland. This article is an open access article distributed under the terms and conditions of the Creative Commons Attribution (CC BY) license (https:/ / creativecommons.org/licenses/by/ $4.0 /)$.

\begin{abstract}
In this study, we investigate how companies can contribute to achieving a circular economy (CE) in the electronics industry viewed through the lens of dynamic capability. In particular, we examine how companies can contribute through idiosyncratic ecopreneurship according to dynamic capabilities with three points: the dynamic capabilities of established companies, the formation of ecopreneurship according to idiosyncratic dynamic capabilities, and the shaping of a CE through the interplay of ecopreneurship and dynamic capabilities of established companies. We conducted a case study of five leading TV manufacturers (Samsung, LG, Sony, Hisense, and TCL) to verify our conceptual framework, which we derived from a literature review. The case study shows that a company's contribution to the CE and ecopreneurship type largely depend on a combination of dynamic capabilities and business strategies. Based on the case study results, we derived managerial implications with three points: the approach of leading companies to $\mathrm{CE}$ with consideration of business strategies, leveraging ecopreneurship to gain competitiveness in the market, and the influence of micro- and meso-level dynamic capabilities on a company's contribution to CE.
\end{abstract}

Keywords: technology standards; eco-innovation; ecopreneurship; dynamic capabilities; circular economy

\section{Introduction}

Eco-friendly products and the United Nations (UN) Sustainable Development Goals (SDGs) confirm that there is a lively discussion on sustainability and circular economy (CE) worldwide [1,2]. The major difference between these two concepts is that $\mathrm{CE}$ emphasizes the role of the manufacturer by highlighting the regenerative process of resources, such as waste management, recycling, refurbishing, and environmental product design, while sustainability focuses on the benefits for future generations through a balanced integration of economic performance and environmental resilience [3]. Considering the environmental impact of the products we use, it is obvious that manufacturing industries have an important role in achieving a CE in society [4]. Based on wide discussions of the manufacturer's role in achieving a CE and global interest in the environment, the environmental impact of products has received attention from society $[5,6]$.

Rising interest in environmental issues makes countries apply policy measures such as technology standards and technical regulations to increase manufacturers' awareness of environmental issues, by letting them eco-innovate and manage the quality of products to fulfill such policy measures [7]. Technological policy measures such as the European Union's Ecodesign, Waste Electrical and Electronic Equipment (WEEE), and Restriction of Hazardous Substances (RoHS) directives are well known. Such policy measures and technology standards incentivize manufacturing companies to eco-innovate, so that they can achieve a privileged market position and create new opportunities for business [8-10]. In terms of the response, the techniques of response vary according to the company's 
dynamic capabilities and ecopreneurship, which is influenced by idiosyncratic dynamic capabilities [11,12]. As far as we can recognize, the role of technology standards in setting and providing rules in the marketplace strengthens their influence on manufacturing companies, and even shapes the industrial movement toward a $\mathrm{CE}$ by providing incentives to eco-innovate $[13,14]$.

Based on the growing recognition of $\mathrm{CE}$, environmental regulations and eco-innovations have been studied as influential factors that affect the business activities of manufacturing companies, by setting the scene for raising their environmental awareness [4,15-20]. Most studies have investigated the influence of environmental regulations on the product development process $[4,5,7,21-23]$. Despite the number of studies on the relationships between $\mathrm{CE}$, business activities, and environmental regulations, studies focusing on how a company can contribute to a CE through idiosyncratic ecopreneurship, based on the company's inherent dynamic capabilities, are still lacking. With this in mind, we investigated the way a CE is shaped in the digital TV industry through the ecopreneurship of manufacturing companies, as seen through the lens of dynamic capability.

In this study, we first suggested a conceptual framework for the way the industry's attitude toward a CE is shaped and consolidated based on a literature review of existing studies that are relevant to the research objective. Subsequently, a case study on outstanding companies in the digital TV industry field, which is technology-intensive and sensitive to environmental issues, verified the proposed conceptual framework. For the case study, content analysis was conducted on relevant qualitative data, such as media articles, news from corporate websites, and corporate social responsibility (CSR) reports, in order to investigate the latest ecopreneurship tendencies of leading companies in the electronics industry. Five leading companies were included in the case study: Samsung Electronics (Suwon, Korea), LG Electronics (Seoul, Korea), Sony (Tokyo, Japan), Hisense (Qingdao, China), and TCL (Huizhou, China). Using the case study, we examined the ecopreneurship of the digital TV industry based on following research questions:

- RQ 1: What kind of dynamic capabilities do established companies in the digital TV industry have?

- $\quad$ RQ 2: How do idiosyncratic dynamic capabilities shape the unique ecopreneurship of each company?

- RQ 3: How do established companies shape CE through the interplay of ecopreneurship and dynamic capabilities?

This study contributes to the existing research in the CE field and fills a research gap by providing a theoretical framework regarding how the industry's participation in and movement toward a CE is shaped based on dynamic capabilities and ecopreneurship. Particularly, understanding ecopreneurship is important to the electronics industry, because increasing issues related to the environmental impact of electronic products are inevitable [24-26]. For this reason, examining the ecopreneurship of established companies in the digital TV industry can provide insights on how companies can contribute to a $\mathrm{CE}$ while benefitting from pursuing ecopreneurship, such as sustaining a competitive position in the market. By analyzing cases of leading companies in the digital TV industry, we provide evidence on how such companies respond to the flow of a CE by leveraging dynamic capabilities.

The remainder of this study is structured as follows: Section 2 presents the theoretical background and Section 3 introduces the research method of this study. Section 4 develops the research framework based on the literature review, and Section 5 analyzes the cases of five leading companies in the digital TV industry, with a focus on ecopreneurship based on dynamic capability (DC). Finally, Section 6 discusses implications for companies in terms of shaping a CE by implementing ecopreneurship according to various dynamic capabilities and agendas for future research. 


\section{Theoretical Background}

\subsection{Circular Economy and the Digital TV Industry}

The economists Pearce and Turner were the first to introduce the concept of a CE [27]. There is no universal definition of $\mathrm{CE}$; however, various definitions from research articles and CE standards have one thing in common: a CE pursues a circular model of consumption and production, compared with the traditional linear model, which is an open-ended economic system $[1,2,13,16,17,28-30]$. In terms of the main objective, a CE aims to avoid impacts on the environment and human health through the 3 Rs-reduce, reuse, and recycle [7,15,16,29]. Recently, McDonough and Braungart [15,31] introduced a fourth $R$, regulation, based on the notion that regulations can reduce environmental damage.

A CE promotes value creation by reducing resources, costs, and impacts, and boosts competitiveness and creates new business opportunities and innovative methods of production and consumption [6,29]. Eco-innovations with a focus on CE are mostly concentrated in the manufacturing sector [32]. The electronics sector has many chances to contribute to a CE; for example, by recovering valuable materials from electronic waste (resource efficiency) and reducing energy consumption (energy efficiency) [33]. Particularly, the digital TV industry has a tendency for rapid technological changes and subsequent shorter product life cycles; therefore, manufacturers in this industry are scrambling to introduce eco-innovative products to the market $[25,26]$. EU countries are recognized as pioneers in environmental regulations; for this reason, the EU's environmental regulations have received attention from researchers in connection with the CE [5,15]. The European Commission (EC) implemented ecodesign requirements that set minimum energy performance requirements and energy labelling that set a scale based on an energy efficiency index for TVs in 2010 [34]. In 2019, the revised version of these ecodesign requirements and energy labelling was announced, which includes resource efficiency requirements, such as repairability and a new scale for energy labelling [34]. The EU's introduction of resource efficiency requirements in ecodesign requirements reflects global trends of emphasizing resource efficiency; a shift toward circularity and efficient resource usage is critical, since global resource demand is expected to increase $[35,36]$.

\subsection{Environmental Regulations and Eco-Innovation}

Eco-innovation plays an essential role in achieving a CE, since it emphasizes the environment, which makes it suitable for fostering the transition from the traditional linear economy to a CE $[8,37,38]$. In terms of eco-innovations, there are three concepts that are essential to understand and clarify when discussing a company's ecopreneurship: environmental regulations, technology standards (i.e., formal standards), and complementary instruments (i.e., conformity assessment and labelling). Regulations are general rules and specific actions developed and implemented by government authorities with the aim of influencing the behavior of concerned stakeholders [39-42]. Considering the meaning of regulations, environmental regulations are defined as general rules and specific actions enacted by government authorities in order to achieve goals, such as reducing negative impacts on the environment and managing natural resources [43]. Technology standards, particularly formal standards, are developed by standard setting organizations (SSOs) based on negotiations among stakeholders who participate in the standardization process, and adopting standards is mostly voluntary $[24,39,44]$. In this study, the term "technology standards" refers to those directly linked to regulations that are mandatory for concerned parties [39]. The application of environmental regulations is supplemented by complementing instruments, such as conformity assessment and labelling [24,45,46]. Companies can demonstrate that their products conform to specific requirements under the regulations by conducting conformity assessments $[44,47]$. For example, the EU's ecodesign directive requires conformity assessment of products covered under the directive before they are placed on the market [48]. Labelling is frequently used under environmental regulations to provide information to consumers, such as a product's performance (e.g., energy consumption and efficiency) and environmental impact [45,46]. 
In general, environmental regulations and associated technology standards are strong drivers of the adoption and implementation of eco-innovation by companies $[17,38]$. In some cases, environmental regulations and associated technology standards do not facilitate eco-innovation, because the influence varies according to market conditions; for example, companies with businesses closer to consumers tend to be easily affected by such regulations and standards [13]. Environmental regulations and associated technology standards act as a "focusing device" for companies by suggesting goals and setting requirements aimed at facilitating eco-innovation $[17,19]$. For example, the EU's WEEE directive, a well-known environmental regulation, requires manufacturing companies to meet a minimum e-waste collection rate and specifies substances and components that need to be removed for selective treatment due to the environmental risks they might cause $[49,50]$. In response, companies not only eco-innovate to comply with the environmental regulations, but also pay more attention to eco-innovation by developing new technologies and products [51].

\subsection{Dynamic Capability View of Ecopreneurship}

In the traditional definition of "entrepreneur," an entrepreneur is someone who creates a new business, such as a start-up; in a broad sense, entrepreneurs can be interpreted as people who find and seize business opportunities and translate them into products or services [52]. With this perspective, entrepreneurship can be defined as sensing opportunities and creating or extracting value from those opportunities [53-55]. Meanwhile, "ecopreneurship" and "ecopreneur" extend the concept of traditional entrepreneurship. Ecopreneurs are people who have an interest in environmental and societal issues associated with their business; they earn profits while reducing environmental impacts through eco-innovation [56,57]. The main goal of ecopreneurship is to make profits while contributing to solving environmental problems [58]. In this sense, ecopreneurship is a process of identifying and capturing opportunities that minimize environmental impacts while creating value for consumers and bringing profits in return [57].

Nowadays, consumers are willing to pay more for eco-friendly products that provide energy-efficient features, produce fewer emissions, or contain lower levels of hazardous substances $[17,19]$. Accordingly, the eco-innovation of products is connected to cost-leadership and companies' product differentiation strategies $[17,19,20,38,51]$. Manufacturing companies are under the strongest pressure to eco-innovate compared with other business sectors, specifically the service sector, since they occupy the closest position to the final consumers in the market [19,59]. Companies continuously monitor market trends and invest in innovative capacities, particularly R\&D, in order to explore and capture business opportunities [49,55].

Since consumer demand for and market trends toward eco-friendly products are increasing, many scholars have discussed the importance of ecopreneurship and ecoinnovation for companies that wish to attain a competitive position in the market when considering the potential positive influence of eco-innovation, such as market competitiveness and revenue $[8,17,19,38,60]$. Eco-innovation delivers various benefits to companies and to society: resource efficiency (reduced resource consumption, such as energy and raw materials), cost reduction through the use of recycled materials or better use of raw materials, innovations related to the application of new technologies or processes, compliance with relevant regulations, and corporate image improvement $[30,52,61]$.

Moreover, the concepts of ecopreneurship and ecopreneurs are highlighted in the business field based on the idea that eco-innovation needs to be examined through the lens of business strategy $[4,38,56,57,62]$. Ecopreneurship is influenced by a company's dynamic capabilities, which is its "ability to create, reconfigure, and integrate internal and external competences in response to rapidly changing business environments", and subsequently influences eco-innovation, such as eco-friendly technology and products [5,11,20,37,63-65]. Dynamic capabilities can be categorized based on their level of governance [66]. The micro-foundation level includes sensing, seizing, and reconfiguring capabilities, whereas 
the meso-level includes absorptive, adaptation, and innovative capabilities [66]. These capabilities form the dynamic capabilities of a company and influence how the company will respond to a changing business environment (e.g., ecopreneurship induced by environmental issues in the market) [11,66-70]. In management studies, these dynamic capabilities have been receiving attention from scholars in terms of explaining how a company can secure and retain a competitive advantage in the market $[20,37]$. In line with this, the dynamic capabilities provide the underlying reasons why companies move toward a $\mathrm{CE}$ by adopting eco-innovations as their strategy to compete in the market [63,65].

\subsection{Research Gap}

Studies on CE and eco-innovations, which began in 2000, have highlighted various issues, including green growth, sustainability in the market, and factors affecting ecoinnovation, such as internal and external drivers [64,71]. Eco-innovation in manufacturing industries has been receiving more attention from companies, governments, and academia on the back of global interest in a CE $[16,17,72]$. This trend is particularly evident in the electronics industry, since electronic products face many environmental regulations and technology standards $[14,59]$. This is partly due to the attributes of electronic products, which have a short life cycle leveraged by a rapidly changing market environment, such as technological improvements, and fast-changing consumer purchasing patterns [16,49,71-73]. Despite the empirical evidence and studies showing manufacturing companies' contributions to mitigating environmental impact through eco-innovations, studies investigating eco-innovation with a focus on how dynamic capabilities shape ecopreneurship are still lacking [64,73-75]. Moreover, existing studies are limited to providing possible motives for a company to eco-innovate and highlighting the role of environmental regulations as external stimuli for eco-innovation. However, various ecopreneurship types among companies are still under question, and how each company's idiosyncratic ecopreneurship contributes to shaping a CE in the market needs to be further investigated.

\section{Research Methods}

We focused on digital TV manufacturing companies for two reasons: first, the digital TV industry is a representative example of a dynamic environment characterized by a high level of market uncertainty and rapid technological change, and second, there is a significant environmental impact of digital TVs, such as a high proportion of household energy consumption and valuable and hazardous materials in end-of-life TVs [76-78].

Figure 1 shows that companies in the digital TV industry experienced upheaval during the period 2008-2017 based on the share of shipments depending on unit sales. The Japanese manufacturers, Sony and Toshiba, lost slight market share to the Chinese manufacturers, TCL and Hisense. Considering the upheaval in the TV market among traditional strong players and rising stars, we decided not to limit the targets of the case study to only the top three players. As can be seen in Figure 1, shipment shares of the top five companies make up more than half of the total shipment shares in the global TV market, which corresponds to the Pareto principle. Based on the discussions above and considering the latest trends in the global TV market, we selected five digital TV manufacturers-Samsung, LG, Sony, Hisense, and TCL—according to the turnover in 2019 (see Figure 2). 


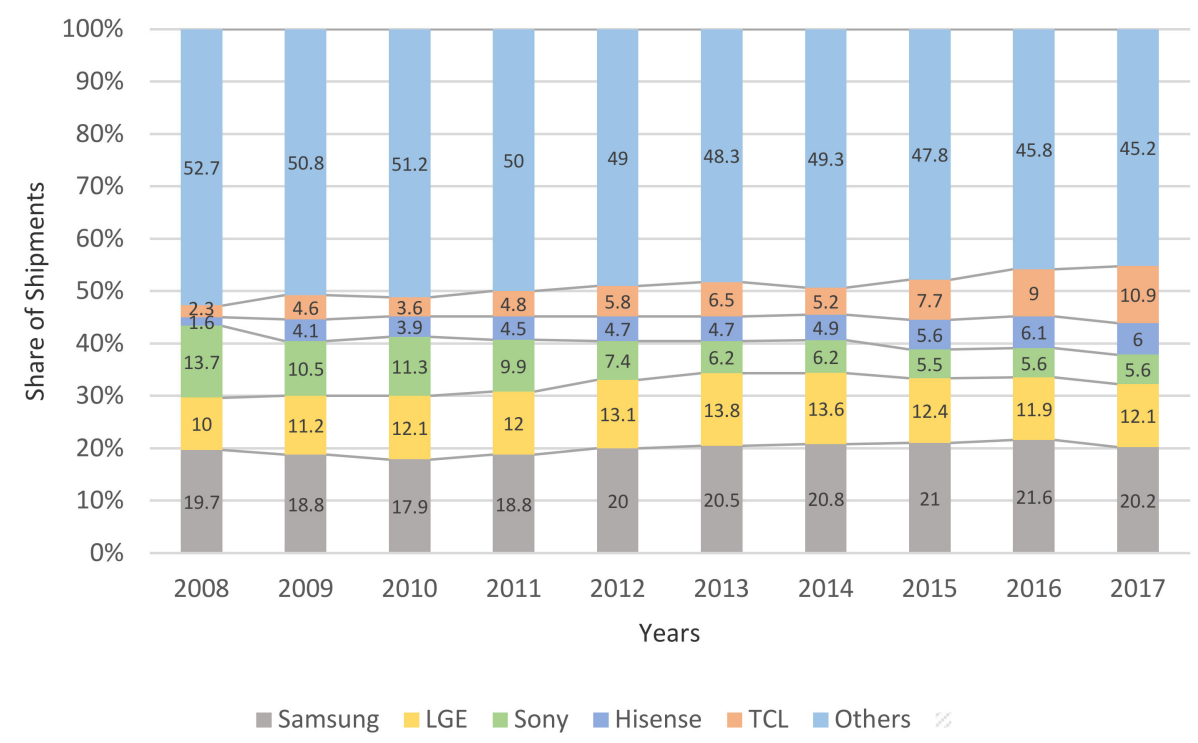

Figure 1. Global TV market share, based on shipment shares from 2008 to 2017 (Sources: NPD Group, DisplaySearch, TCL, IHS, Sigmaintell).

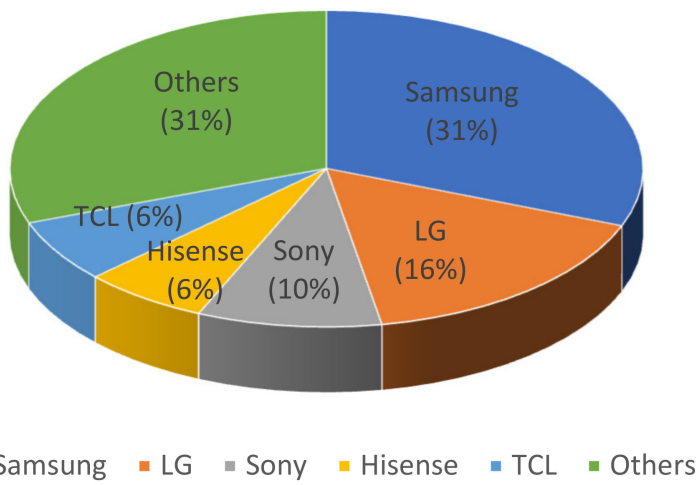

Figure 2. Global TV sales by manufacturer in 2019 (Source: IHS Markit, https:/ /www.ihsmarkit. $\mathrm{com} /$, (assessed on 29 March 2021)).

Figure 3 describes our research procedure, which started with building the research framework according to the literature review, followed by a validation process through case study. Based on the arguments in the previous section, we use dynamic capability as the underlying theoretical framework to explain the various forms of ecopreneurship in manufacturing companies, and why companies eco-innovate in response to the growing awareness of a CE in the market. In order to construct the conceptual framework, we reviewed relevant articles collected from the Web of Science (WoS) and ScienceDirect, which provide top-tier and up-to-date journal articles, to access plentiful research on the subject matter based on a keyword search (including circular economy, standards, ecodesign, and innovation) $[38,79]$. We used snowball sampling, which extracts relevant articles from the references of each article, to complement the data collection from the two databases $[76,80]$. Some 332 articles were collected from the primary keyword search, and after screening the abstract and full text, 50 articles, including 3 duplicates, were excluded. We collected 16 additional articles through snowball sampling; therefore, a total of 63 articles were selected for the review. Key elements shaping the CE in the market were identified based on the literature review, which comprise the conceptual framework. 
$<$ Literature Review $>$

\begin{tabular}{l} 
Article Collection \\
- Article source: WoS, ScienceDirect, and \\
snowball sampling \\
- \\
\hline
\end{tabular}

- Article Screening

- Screening primary articles through abstract and full-text review
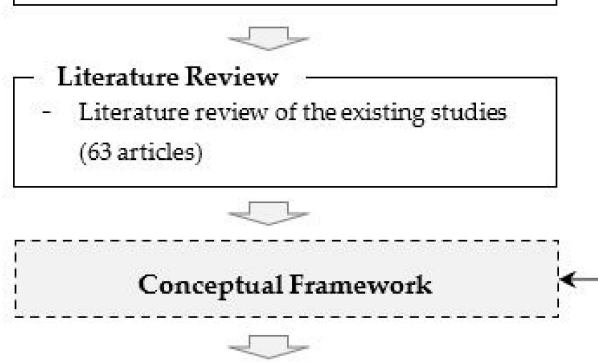

Validation of the proposed research framework and the initial propositions

Interpretation of technology standard's influence on the way in which companies respond to the flow of the CE through the lens of DC

Figure 3. Research procedure.

We validated the proposed conceptual framework and associated propositions using case studies of leading companies in the electronics industry. The case study aimed to provide an in-depth description and analysis of a certain event, which is considered appropriate for investigating research objectives [80,81]. Mass media, such as newspapers, industrial magazines, and corporate websites, were used as a major data source of qualitative research by a number of studies, since they provide plenty of valuable news relevant to certain events or companies for specific periods of time $[76,80]$. The time frame of the search was from 2010 to 2019. The year 2010 is a meaningful starting point, because the shift toward a CE had already begun, based on a key policy, the EU ecodesign and energy labelling directives $[15,24]$. Considering this, cases were subjected to content analysis using various sources of publicly available media sources, such as corporate websites, CSR reports, newspapers, and industrial magazines (see Table 1).

Table 1. Data sources for case study.

\begin{tabular}{ccc}
\hline Source & Description & Number of Documents \\
\hline Corporate websites & General information on company policies and major achievements & 51 \\
through corporate newsrooms & Published annually regarding companies' contributions to society and \\
the environment & 19 \\
CSR reports & $\begin{array}{c}\text { A renowned American media website offering industry news, technology } \\
\text { articles, and product reviews with a focus on the electronics market } \\
\text { Industry-specific media outlet established in 2009 that provides news } \\
\text { and reviews on the TV and display industry }\end{array}$ & 38 \\
\hline
\end{tabular}

Content analysis is defined as an "analysis of the manifest and the latent content of a body of communicated material through classification, tabulation, and evaluation of its key symbols and themes in order to ascertain its meaning and probable effect" [82]. Content analysis is frequently used in studies that aim to obtain an in-depth understanding of a specific topic based on qualitative data, such as research articles, news articles, and 
magazines [76,80,81]. There are two approaches, inductive and deductive content analysis (also known as conventional and directed content analysis), depending on the purpose of the study and the availability of previous knowledge $[83,84]$. Considering the availability of existing studies and our research objective, we adopted the inductive content analysis approach in order to synthesize fragmented knowledge on the way to shape a CE through the various types of ecopreneurship in manufacturing companies. Our content analysis procedure included two parts: extracting the original intention or idea from the text, and developing an interpretation from the analysis [76,80]. The first part of content analysis involves qualitatively coding the text, which helps in extracting core constructs from the collected documents. In this study, we used Atlas.ti, which is computer-assisted qualitative data analysis software (CAQDAS). Among various coding methods, we applied descriptive coding, which summarizes the data content into words or short sentences [85]. According to Wolcott [86], descriptive coding is essential groundwork for further analysis and interpretation. We extracted content, such as the company's ecopreneurship, dynamic capabilities, and eco-innovations using descriptive coding. After finishing the qualitative coding, we derived meanings from the coding results by relating codes and categorizing them based on the core themes, which is also known as axial coding [85]. Figure 4 illustrates the content analysis procedure, which briefly shows major features such as meaning extraction and a categorization of extracted meanings.

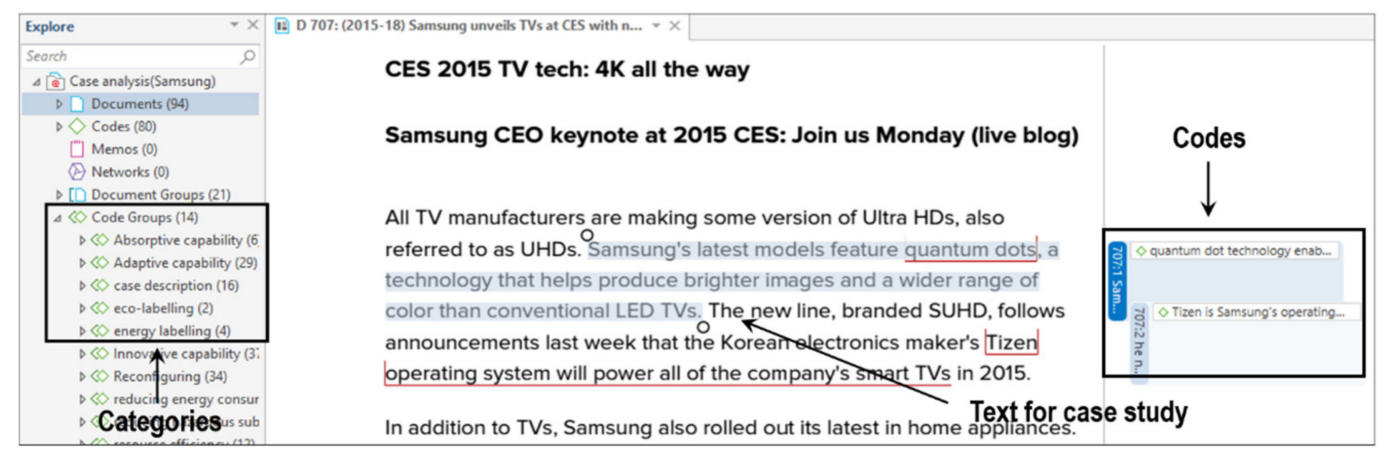

Figure 4. Content analysis using Atlas.ti.

\section{Conceptual Framework}

Based on the literature review, we derived key elements and developed the conceptual framework shown below (see Figure 5). Studies focusing on the market competencies of companies have discussed the conceptual framework of competitive advantage with a focus on dynamic capabilities, separating the framework into three parts: antecedents, processes, and outcomes $[11,87,88]$. Considering this, our conceptual framework is composed of five elements: stimuli (i.e., antecedents); dynamic capabilities (i.e., processes); ecopreneurship (i.e., processes); eco-innovation (i.e., outcomes), which is connected to contributing to achieving a CE; competitive advantage (i.e., outcomes). These five elements show a cyclic aspect by bridging between competitive advantage and stimuli through factors that motivate companies, such as technology obsolescence and consumer expectations, and lead to the start of the subsequent cycle, considering that competitive advantage market dynamism is transient, not sustainable $[70,89,90]$. This reflects that companies strategically respond to a continuously changing market by utilizing dynamic capabilities; as a result, this will lead to eco-innovation influenced by the environmental needs of the market. As we can see in Figure 5, a company's eco-innovation efforts, such as energy efficiency, resource efficiency, and reduction in negative environmental impact, help us to get one step closer to a CE. 


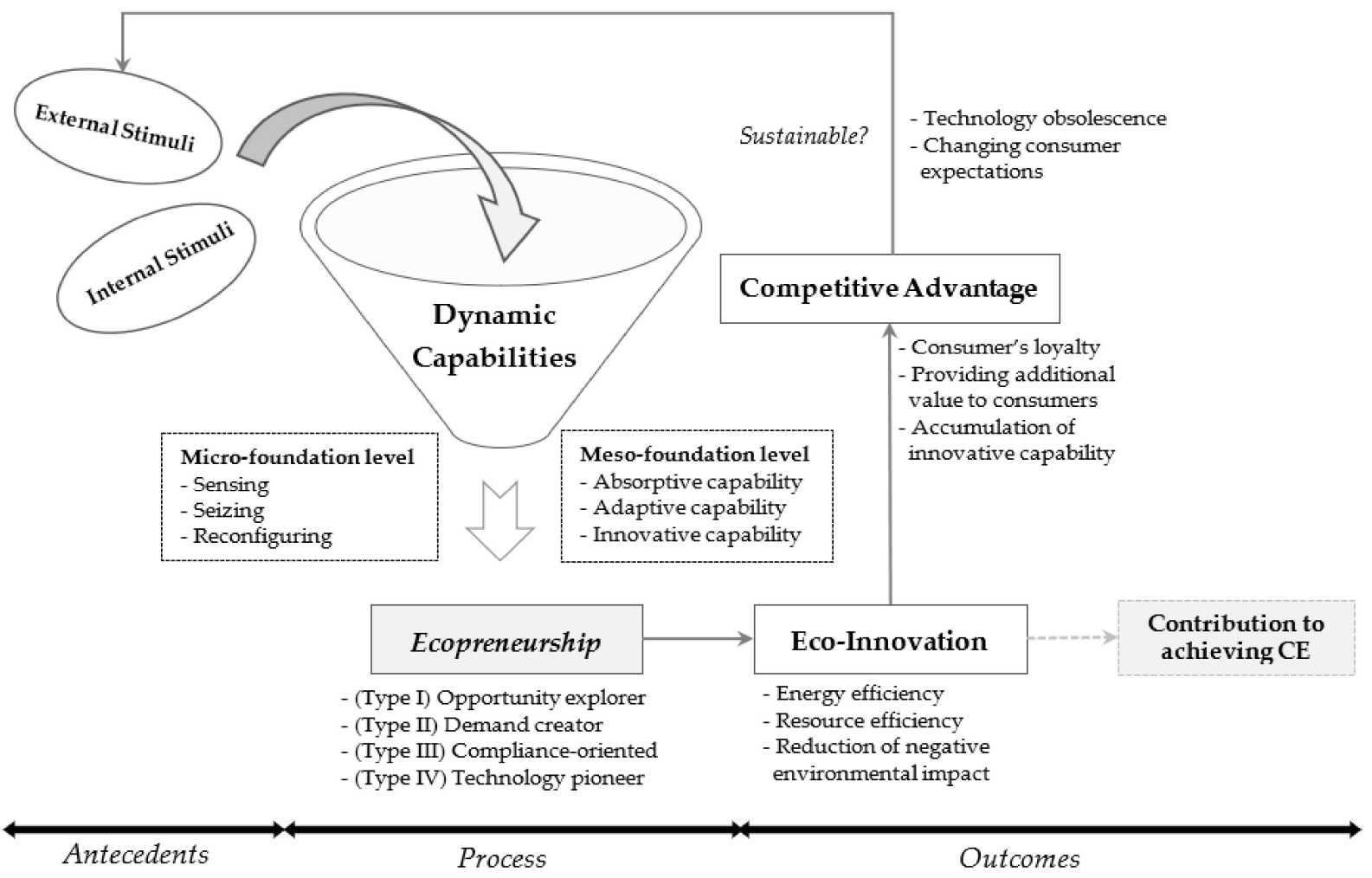

Figure 5. Conceptual framework.

\subsection{Stimuli (Antecedents)}

Stimuli are antecedents of a company's eco-innovations by giving the company several reasons to eco-innovate $[37,57,91,92]$. They can be divided into internal and external stimuli, depending on their attributes [43]. Internal stimuli come mostly from the company's inherent conditions and an executive's desires [20,92]. Internal stimuli include the company's desire to improve its corporate image, green marketing strategy, top management's commitment, and commercial benefits, and capture a new opportunity to create value $[57,62,92,93]$. General types of external stimuli are environmental regulations, consumer or market demands, supply of eco-efficient materials, and a competitor's launching of eco-innovative products $[4,17,51,63,93]$. Among external stimuli, environmental regulations are the most influential driver of eco-innovation $[19,38,51,64,91,92]$. Technology standards and labelling are also frequently discussed as external stimuli of eco-innovation $[15,24,28,51,72,94]$. Technology standards stipulate requirements related to energy efficiency and restrictions on the concentration of hazardous substances [24,72]. Labelling schemes require manufacturers to provide information on the environmental impact caused by product usage or allows manufacturers to attach a specific mark that verifies that products either fulfill environmental requirements or cause less environmental impact [28,94,95]. Sometimes, external stimuli can trigger internal stimuli by making companies pay attention to the possible benefits of eco-innovation $[4,17,93]$. Based on this, we postulate the following research propositions:

Proposition 1a. External stimuli, such as environmental regulations and consumer demand, facilitate a company's internal stimuli for eco-innovation.

Proposition 1b. Internal stimuli facilitate a company's contribution to the CE by increasing eco-innovation. 


\subsection{Ecopreneurship through the Lens of DC (Process)}

DC emerges from the traditional resource-based view (RBV), which emphasizes that a company's sustainable competitiveness comes from the superiority of its idiosyncratic resources $[76,80]$. According to RBV, a company's outstanding performance originates from its various resources, therefore, companies have to choose the best way to capture external opportunities that maximize the exploitation of resources and capabilities $[11,90,96]$. Meanwhile, DC focuses on the company's processes (or abilities) for exploiting resources in order to be competitive $[11,66,89,97]$.

A company's dynamic capabilities exist on two levels: the micro-foundation level, which forms the basis, and the meso-foundation level, which is related to the implementation of micro-level dynamic capabilities [66]. The micro-foundation level consists of three capabilities: sensing, seizing, and reconfiguring. These capabilities are closely related to creating and capturing value [67]. Sensing defines a company's ability to be aware of changes in demand based on understanding market signals and trends $[65,97]$. Sensing builds on an individual's capacity and an organizational process connected to exploring new opportunities $[67,68,87,88,98]$. Sensing is an important dynamic capability for companies, because it enables them to identify and cultivate opportunities to stay competitive in the market [97]. When new opportunities are sensed, the seizing capability helps companies address identified opportunities in new products, services, or processes $[67,97,98]$. Reconfiguring capability is a company's ability to recombine and reconfigure its resources to maintain market fitness to sustain a profitable position $[87,88,97,98]$.

A company's business strategy implementation largely depends on inherent mesolevel capabilities, such as adaptive, absorptive, and innovative capabilities, which are influenced by the micro-level capabilities $[66,88,99]$. Adaptive and absorptive capability can be distinguished depending on what is emphasized in terms of the company's response in the market $[66,99]$. Adaptive capability is defined as a company's ability to identify and take advantage of market opportunities by responding to changing market trends, adapt their scope of business in response to business environment changes, and reallocate resources based on monitoring consumers and competitors [99]. Absorptive capability is a company's ability to recognize the value of new knowledge and learn it to make it their own [99]. Therefore, companies with a high level of absorptive capability tend to show a strong ability to learn new knowledge and technology and transform it into their own knowledge $[66,99,100]$. Innovative capability, as the word itself indicates, is a company's ability to develop new products or services (i.e., product innovativeness), to pioneer a new market (i.e., market innovativeness), or to reconceptualize the way to do business in a whole different way (i.e., strategic innovativeness) $[99,101]$. Innovative capability explains a company's inherent innovativeness in achieving a competitive advantage in the market through new product launches or an expanded business scope [99].

In terms of the movement toward a $\mathrm{CE}$, each company's response to the demand for a $C E$ in the market varies according to their strongest dynamic capabilities. The term "ecopreneurship" describes a company's response to the CE and environmental issues [102]. Ecopreneurship is a portmanteau word that combines "eco-" and "entrepreneurship," and is sometimes called environmental entrepreneurship $[9,103]$. Ecopreneurship is generally defined as conducting business and seeking new opportunities in a way that is helpful for both a company's competitiveness and environment protection $[9,102,104]$. Assuming a narrow perspective, ecopreneurship is often described as creating a new company related to natural resources, for example, an organic products business [99]. In this study, we exclude this narrow definition of ecopreneurship because it lacks the eco-innovative perspective, and subsequently tends not to be closely related to achieving a $\mathrm{CE}$. The manifestation of a company's ecopreneurship is closely related to external and internal stimuli, such as a government regulation and technology standards (compliance-driven ecopreneurship), expected positive incentives from eco-friendly behavior (market-driven ecopreneurship), and consumer demand related to environmental value (value-driven ecopreneurship) $[9,88]$. The embodiment of ecopreneurship triggered by external and internal stimuli varies accord- 
ing to the company's various dynamic capabilities, which emanate from various conditions, such as past managerial decisions, that shape its business direction and activities [100].

A company's ecopreneurship is driven by various factors, and can be categorized into several types, such as innovative opportunist, visionary champion, ethical maverick, and ad hoc enviropreneur [88]. Since the concept of ecopreneurship is still in the development stage, there are no agreed upon conceptual definitions for the types of ecopreneurship $[9,56,102]$. As indicated in Figure 6, we suggest four types of ecopreneurship based on the content analysis, considering the existing discussions on eco-innovation and ecopreneurship. We tabulated four types using a quadrant graph, where the vertical axis represents the level of market orientation and the horizontal axis indicates the level of technology orientation.

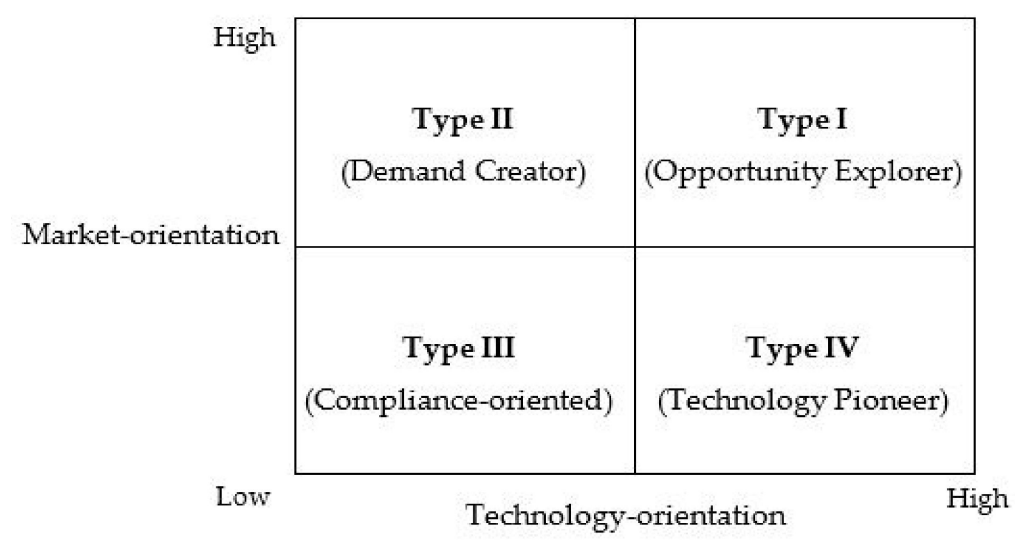

Figure 6. Types of ecopreneurship.

We named type I opportunity explorer, because this type requires a company to have a keen sense of consumer needs and an eye for technological trends in the market [97]. Since type I involves a high level of both market and technology orientation with a focus on environmental concerns, events classified as type I can represent a company's current business focus $[10,105]$. Type II shows a high level of market orientation and a low level of technology orientation and represents companies that have a significant interest in consumer demands and market trends. Companies that belong to type II try to impress consumers with novel but practical products or services that they introduce to the market and are less focused on technological innovativeness and advancement than type I [8].

In comparison with the other types, type III can be described as mediocre innovations or changes in products and services from the common view. Most type III ecopreneurship is driven by environmental regulations and technology standards and complementing instruments under the environmental regulations; therefore, we named type III complianceoriented ecopreneurship $[9,10]$. Type IV shows a low level of market orientation and a high level of technology orientation. For this reason, companies that drive technology push are generally categorized as type IV. This type emphasizes technological development and enhancement to create value and, subsequently, competitive advantage in the market [38].

Proposition 2a. A company's inherent micro-level dynamic capabilities form the meso-level dynamic capabilities.

Proposition 2b. A company's dominant meso-level dynamic capabilities influence the way it shapes its ecopreneurship and position in the market. 
Proposition 2c. The various forms of ecopreneurship are the result of discrepancies between the dynamic capabilities of different companies.

\subsection{Eco-Innovation (Outcomes)}

The term "eco-innovations" was first coined in 1996 by Claude Fussler and Peter James in their book Driving Eco-Innovation: A Breakthrough Discipline for Innovation and Sustainability [99]. In general, eco-innovations are defined as innovative products and processes that reduce environmental impacts while helping in the transition toward a CE $[9,19,38,63-65,92,103,105]$. Fundamentally, the concept of eco-innovation encompasses two perspectives: the influence of innovation on the environment, and the intention of companies to reduce their environmental impact $[8,91]$. The former is related to the positive influence of eco-innovation, and the later indicates its drivers. In terms of policy, eco-innovations are viewed as channeling financial support and $R \& D$ investments into environmentally friendly technologies to develop a more sustainable environment, due to the positive socioeconomic influence [103].

As the outcomes of a company's response to internal and external stimuli, ecoinnovations vary according to the company's ecopreneurship, influenced by endogenous dynamic capabilities $[9,12,67,69]$. There are many different views on the types of ecoinnovation, such as incremental and disruptive eco-innovation [8]; product, process, and organizational eco-innovation; environmental technologies; environmental R\&D; and patented inventions [9,92]. As indicated in Figure 7, Kiefer et al. [37] suggested five types of eco-innovation: continuous improvement, externally driven, radical and technology push, systemic, and eco-efficient eco-innovation. These five types, suggested by Kiefer et al. $[10,37,105]$, categorize eco-innovation depending on the drivers and on the level of market and technology orientation.

Continuous improvement is the most typical type of eco-innovation, which is derived from a company's day-to-day business practices and can be described as "normal" or "by-product" innovation, due to the lack of novelty and the low level of changes it induces $[10,105]$. Similarly, externally driven eco-innovation also shows a low level of technology orientation and is typified as compliance-driven, such as environmental regulations and associated technology standards $[10,105]$. In comparison with continuous improvement eco-innovation, externally driven eco-innovation has a significant influence on a company's business performance, due to the quality signaling effect of regulatory compliance on consumers making purchase decisions $[9,10,51,94,95,103]$. On the other hand, radical and technology push eco-innovation is characterized as bringing a high level of technological change and novelty while considerably reducing the environmental impact $[10,105]$. Systemic eco-innovation causes extensive changes and improvements to the business environment in the same manner as radical and technology push ecoinnovation $[10,105]$. However, systemic eco-innovation is triggered by demand pull, emphasizing new consumers and markets, while radical and technology push eco-innovation is derived by supply push [10]. Eco-efficient eco-innovation is also market oriented, and focuses on increasing a company's competitiveness by achieving eco-efficiency, such as through energy saving and resource efficiency $[10,105]$. Unfortunately, these five types do not seem to be a perfect description for eco-innovation types, because they are not mutually exclusive or completely exhaustive. Despite the efforts to categorize the types of eco-innovation, there is still no unified classification scheme. 


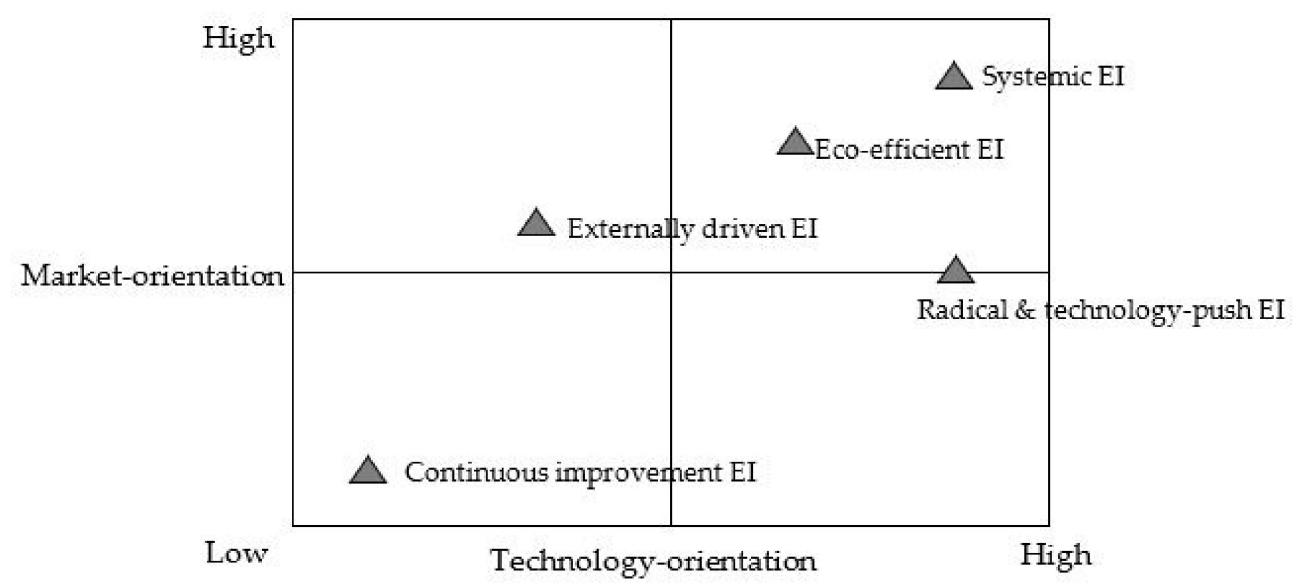

Figure 7. Types of eco-innovation (visualization of five types of eco-innovation from Kiefer et al. (2019)).

Proposition 3a. Eco-innovation with low levels of technology and market orientation tends to be related to a company's compliance with environmental regulations and associated technology standards.

Proposition 3b. Eco-innovation with high levels of technology and market orientation tends to create extensive changes in the industry while contributing to a company's competitiveness.

Proposition 3c. Some types of eco-innovation focus more on complying with requirements or making social contributions rather than gaining a competitive advantage.

\subsection{Competitive Advantage (Outcomes)}

The way in which a company's competitive advantage is created has been studied and discussed by many researchers with various perspectives [11,20,29,37,38,63,65]. Recently, global concerns about environmental impacts related to aspects, such as recycling, restricting the use of hazardous substances, and promoting energy efficiency, have led to increased recognition of the value of eco-innovation by companies as a means of achieving competitiveness $[19,51,56,63,65,106,107]$. Outputs of eco-innovation include energy-efficient products, resource efficiency, products that fulfill ecodesign requirements, products that have conformity marks or labels guaranteeing their quality, and eco-friendly products $[24,30,72,95]$. Regardless of the forms of eco-innovation, such products are generally more competitive than those that are not eco-innovative in three aspects: increased consumer loyalty, additional value for consumers, and accumulated innovative capability $[19,51,72]$.

However, a sustainable competitive advantage is extremely hard to achieve due to rapid changes in the market, such as technological progress, technology obsolescence, and changing consumer demands $[70,89,90,108]$. Therefore, companies continuously seek opportunities to meet consumers' changing expectations for products and respond to technology obsolescence $[19,20,38,56,108,109]$. The opportunity-seeking behavior involved in securing competitive advantage will eventually turn into stimuli and promote a company to eco-innovate $[2,19,20,62,64,93,109]$.

Proposition 4a. A company's eco-innovation is mostly driven by the desire to be more competitive than others in the market.

Proposition $4 \mathrm{~b}$. A company pursues eco-innovation to meet changing consumer expectations and respond to technology obsolescence. 


\section{Case Analysis}

In this section, we analyze the cases of the leading digital TV companies to investigate how they respond to and participate in the flow of the $C E$ based on dynamic capabilities and ecopreneurship as viewed through the lens of DC. In this study, we define an event as an individual event related to eco-innovation, and the evidence category is a set of events that can be put into the same category in terms of eco-innovation type based on their core technology or features. Appendix A provides details of the events and evidence categories. This section consists of three parts: a discussion of each company's various dynamic capabilities, a description of ecopreneurship types observed from the content analysis, and discussion on how to shape the CE through ecopreneurship, as viewed through the DC lens. The first and second parts investigate whether the propositions derived in Section 4 are supported.

\subsection{Dynamic Capabilities of Leading Digital TV Companies}

Overall, dynamic capabilities show a company's capacity to respond to rapid changes and a challenging market environment. As can be seen in Figure 8, leading digital TV companies showed various types of DC. The distinct features of each company's DC are discussed below.
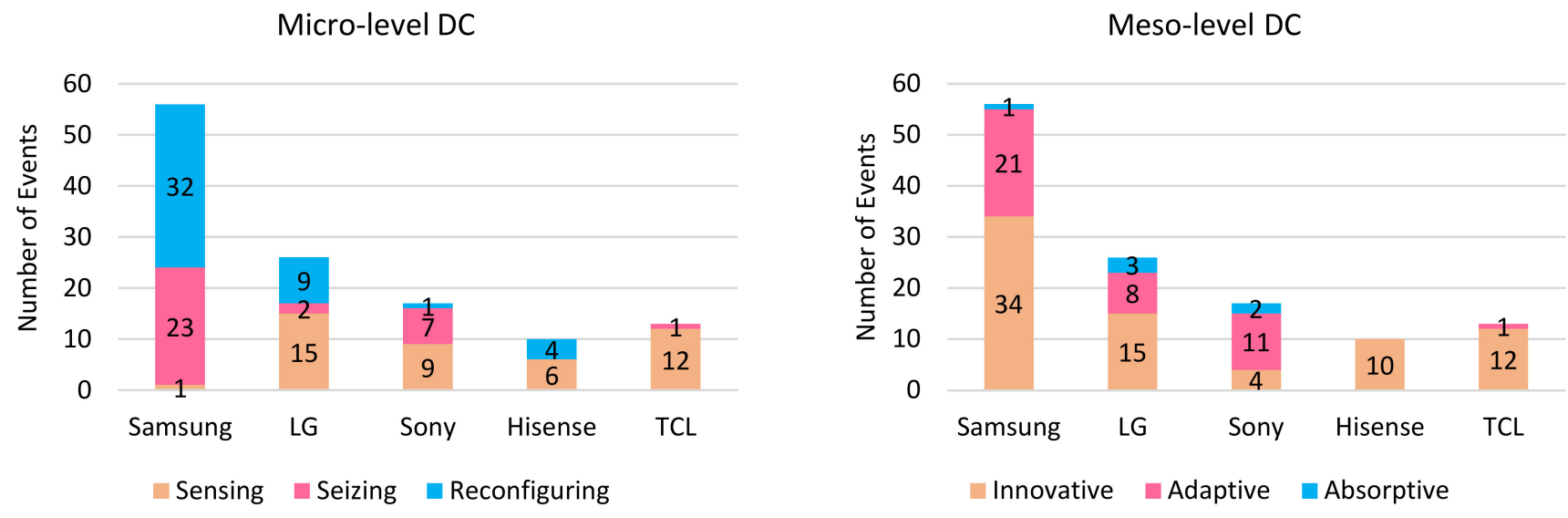

Figure 8. Frequency of events according to micro- and meso-level DC.

In the case of Samsung, most events showed the company's innovative and reconfiguring capabilities in response to changes in market trends (events 1-6, 8, 15-17, 24, 28, 32, $34-40,43-48)$. For example, Samsung introduced various energy-saving functions to its TVs with many names, such as ambient mode, eco sensor, timer plus function, and energysaving mode (events 1-6, 15-17, 30, 33, 56). This implies that Samsung's eco-innovation efforts are driven by the goal of meeting consumer expectations, and subsequently achieving competitiveness in the market. Figure 8 shows that Samsung also has strong adaptive capability over other capabilities, which allows the company to maintain competitiveness by keeping up with the changing market and consumer needs (events 12, 13, 22, 26, 27, 31, $42,49-51,55)$.

In the case of LG, the company showed competence in response to market dynamism, including changing consumer needs and regulatory requirements that must be fulfilled, based on strong innovative, adaptive, and sensing capabilities, as indicated in Figure 8. The analysis results indicate that the combination of micro- and meso-level capabilities helps LG to create and capture value. Based on its inherent sensing capability, LG develops and introduces products with both eco-friendly and innovative features by leveraging innovative capability (events 10, 16-21). In general, these efforts show how LG responds to the changing market environment to secure competitiveness and fulfill consumer expectations for TVs. 
In the case of Sony, the company shows strong adaptive, sensing, and seizing capabilities. Overall, Sony's responses stem from both micro- and meso-level dynamic capabilities, namely seizing, reconfiguring, adaptive, and absorptive capabilities. Based on sensed consumer demands for TVs, such as a wide color gamut, the reproduction of deep black, and enhanced contrast, Sony has continuously quickly adapted to consumer needs to seize market opportunities by providing new features and products to consumers (events 2, 3-10, 12,15-17). These examples indicate that Sony' eco-innovation efforts are largely driven by the aim of gaining competitiveness and facilitating the meeting of consumer expectations.

In the case of Hisense, the company seems to concentrate on innovative and sensing capabilities to catch up with leading companies while satisfying consumer demand by offering TVs that provide pleasing image quality at a reasonable price. In particular, the analysis results show that Hisense positions itself as a budget picture quality contender by pricing TVs lower than its competitors, because the brand name has recently become widely recognized in the market. Satisfying consumer demand while differentiating its products from competitors in the market, Hisense launched TVs with a focus on improved picture quality (events 1-10). For example, the company introduced a brand-new concept of the ULED TV, named ULED XD, based on the dual-layer LCD technology presented at CES 2019 (events 1-4).

In the case of TCL, similar to the other Chinese TV maker, Hisense, this company also shows strong innovative and sensing capabilities by launching TVs with enhanced technologies to follow changing market trends, such as enhanced contrast using local dimming backlighting, and a slim design. In 2019, TCL announced that it was developing a hybrid QLED (H-QLED) display using a blue OLED emitter connected to red and green QLED emitters, which is produced by inkjet printing (events 7,9). Currently, TCL leads in mini-LED technology in the market, which provides better contrast, details, and brightness using more light-emitting diodes (events 1-5). TCL is trying to move upmarket by leveraging mini-LED technology, because its mini-LED-based 8 Series, which launched in 2019 , is the first to the market.

\subsection{Ecopreneurship of Leading Digital TV Companies}

Evidence to support the four types of ecopreneurship was found in the case analysis results (see Figure 9), and that evidence forms the basis of discussion in the next section. We discuss the detailed analysis results of ecopreneurship types based on the evidence category in Appendix A (the related evidence category is given in parentheses). Figure 9 shows that companies exhibit various combinations of ecopreneurship types. Regardless of the distribution ratio of each type, Samsung and LG both exhibited all types of ecopreneurship. However, Sony and TCL only exhibited three types of ecopreneurship (I, II, and III), while Hisense showed two types (I and II). As indicated in Figure 9, the most frequently observed ecopreneurship type of the five leading companies was type I, and the least observed was type IV. According to the analysis results, a company's eco-innovative efforts are based on various dynamic capabilities, including micro- and meso-level; therefore, this gap seems to influence the exhibition of each company's ecopreneurship type, and subsequently verifies Proposition 2c. The following subsection discusses the details of each ecopreneurship type.

- $\quad$ Type I (high market and technology orientation)

Regarding the eco-innovation types discussed above, type I is related to systemic eco-innovation, considering its clear focus on the market, and the influence of demand pull and technology push $[10,106]$. In this regard, the analysis results show that type I is closely related to a company's technological focus: Samsung's MicroLED technology and QLED TV, LG's OLED TV, Hisense's ULED XD, and TCL's mini-LED technology (evidence categories S9, S11, S14, L9, H1, T1). In general, events classified as type I are closely related to a company's innovative, sensing, and seizing capabilities. The analysis results indicate that type I ecopreneurship of leading digital TV companies is mostly concentrated on energy and resource efficiency. For example, Samsung's MicroLED, which uses millions of small LEDs to create images and can turn each LED off; therefore, it can 
reduce energy consumption while reproducing better black, and also provides improved resource efficiency by lowering the chance of burn-in (evidence category S9). These efforts verify the five leading companies' interest in environmental contribution through ecoinnovative features and products.

Type I shows intense competition among digital TV companies to achieve a leading position in the market through technology push: by pushing technology that they stand for or applying to their products the latest technological features favored by consumers, including quantum dot technology, and full array local diming (evidence categories S8-S11, S14, L9, SN1-SN4, SN7, H1, T1-T3). In the case of mini-LED technology, TCL captured market attention by bringing the first mini-LED TV to market. In terms of type I ecopreneurship, a company's active support for its core technology or products indicates its effort to achieve competitive advantage and willingness to lead market trends by developing new technologies that can substitute for current ones. Therefore, a company pursues eco-innovation not only to meet consumer expectations, but to respond to technology obsolescence.

- $\quad$ Type II (high market orientation and low technology orientation)

In terms of type II ecopreneurship, all companies, except TCL, exhibited activities related to type II (evidence categories S1, S7, L1, L6, SN5, H2, H3). Technically, products and services that companies offer based on type II ecopreneurship somehow lack technological advancement compared with the current technology, since their focus is generally not technology-intensive. For this reason, type II emphasizes functions or services in connection with consumer experience and convenience that are suggested but not required, such as TVs with energy-saving functions, an auto-dimming sensor that adjusts brightness according to the viewing environment, motion lighting, and presence sensor (evidence categories S1, S7, S15, L1, L6, SN5). Some events indicated that companies sometimes form alliances or partnerships with other companies that provide a function or service that can fulfill consumer needs (evidence categories L1, SN5). For example, LG and Sony both integrate Google Assistant, an artificial intelligence (AI)-based virtual assistant (evidence categories L1, SN5), with their TVs. Google Assistant allows users to easily control electronic products connected to a smart home device with voice commands, such as turning on/off, switching channels, and searching. In terms of a company's decision to form an alliance or a partnership, it partially depends on its capability to sense new opportunities $[47,77]$.

- $\quad$ Type III (low market and technology orientation)

Typically, type III ecopreneurship is closely connected to Proposition 3a, because it is mostly driven by environmental regulations (evidence categories S12, L2, L7, SN6, T4). Considering consumers' increasing environmental consciousness and the related regulations, companies provide e-waste collection and recycling programs for consumers in order to reduce the negative environmental impact caused by their products. For example, Samsung operates its own e-waste take-back and recycling program, named $\mathrm{Re}+$ (Replus), and LG provides an e-waste take-back and disposal service in 51 countries (evidence categories S12, L7). In order to raise consumers' awareness of e-waste, Sony and TCL support e-waste disposal and recycling in local communities, and also provide useful information in connection with these activities (evidence categories SN6, T4).

In some cases, type III events involve a shift in thinking about the normal usage environment of TVs. In 2014, Samsung announced the multi-power TV, aimed at users in Africa who use TVs with an unstable power supply; when the power supply is not stable, DC power is used to operate the TVs (evidence category S13). Another specialized TV for Africa, the surge-safe TV, was introduced in 2011; it can endure changes in voltage, including power outages, and overvoltage up to $500 \mathrm{~V}$ (evidence category S13). Similar to Samsung, LG developed TVs for consumers in India, the Mosquito Away line (evidence category L8). As the purpose can be assumed from the name, these TVs keep mosquitoes away by using an ultrasonic device. In comparison with other ecopreneurship types, type III tends to develop products for specific consumer needs and release them in a specific 
region. In summary, type III shows a company's social contribution using its technological capacity to develop TVs that can meet regional specific needs while not causing harm to the environment, with features such as low energy consumption and limited hazardous substances.

- $\quad$ Type IV (low market orientation and high technology orientation)

Companies that show type IV ecopreneurship tend to have remarkable technological capabilities, including R\&D experience, resources, and knowledge, which form the basis of their innovation [20]. Moreover, companies that show type IV ecopreneurship continuously invest in developing their technological capacity, such as through R\&D projects and innovation, to explore and exploit business opportunities that can contribute to competitiveness (evidence categories S2-S6, L4, L5) [64]. In comparison with type I, which drives consumer demand based on high levels of market and technology orientation, type IV tends to create new opportunities through supply push [10]. For example, LG in 2012 introduced Cinema 3D TV based on a cinema screen design, which, due to its energy efficiency and eco-friendly quality, earned a verified Environmental Product Declaration (EPD) from the well-known certification body Underwriters Laboratories (UL) (evidence category: L3). LG's Cinema 3D TV has high energy efficiency through the use of local dimming and smart energy saving technology, and creative placement of backlight units at the bottom, while reducing the number of backlights used (evidence category L3).

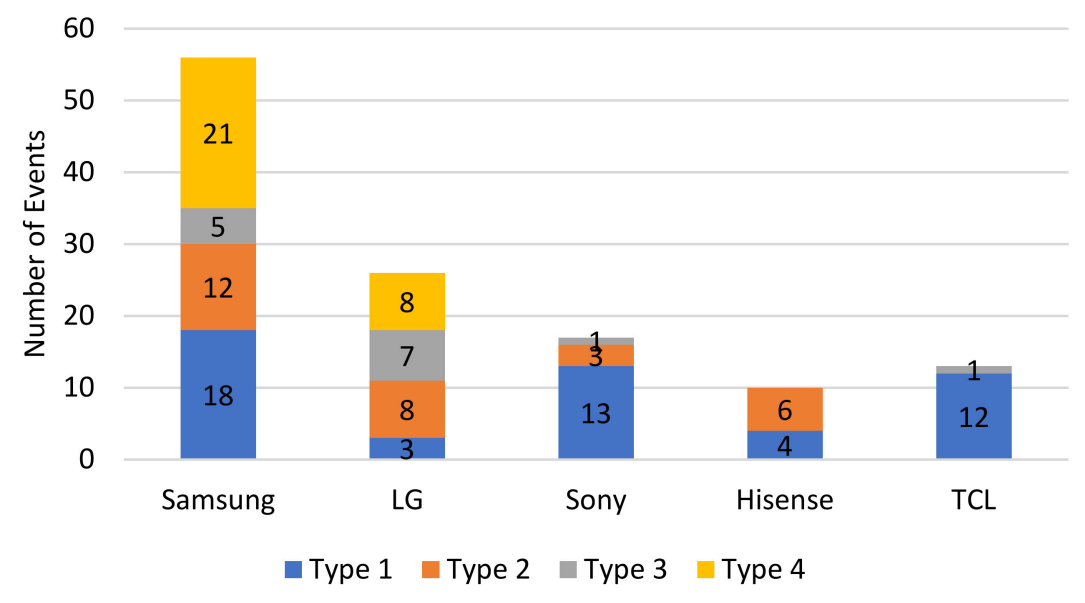

Figure 9. Frequency of events according to ecopreneurship type.

5.3. Shaping the CE through the Ecopreneurship of Established Companies as Viewed through the DC Lens

In general, the leading companies in the digital TV market contribute to achieving a CE through R\&D and eco-innovation in association with their products, such as by reducing their energy consumption, using limited or no hazardous substances, providing e-waste management, and facilitating recycling and using recycled materials. The case study results indicate that established digital TV companies show various kinds of ecopreneurship through their business activities based on idiosyncratic dynamic capabilities, and subsequently influence how the $\mathrm{CE}$ is shaped in the industry. Figure 10 shows the distribution patterns of dynamic capabilities, including the micro- and meso-foundation level from the content analysis, indicating each company's unique inclination in terms of dynamic capabilities and ecopreneurship types. Table 2 describes an overview of the analysis results according to the propositions derived in Section 4. 


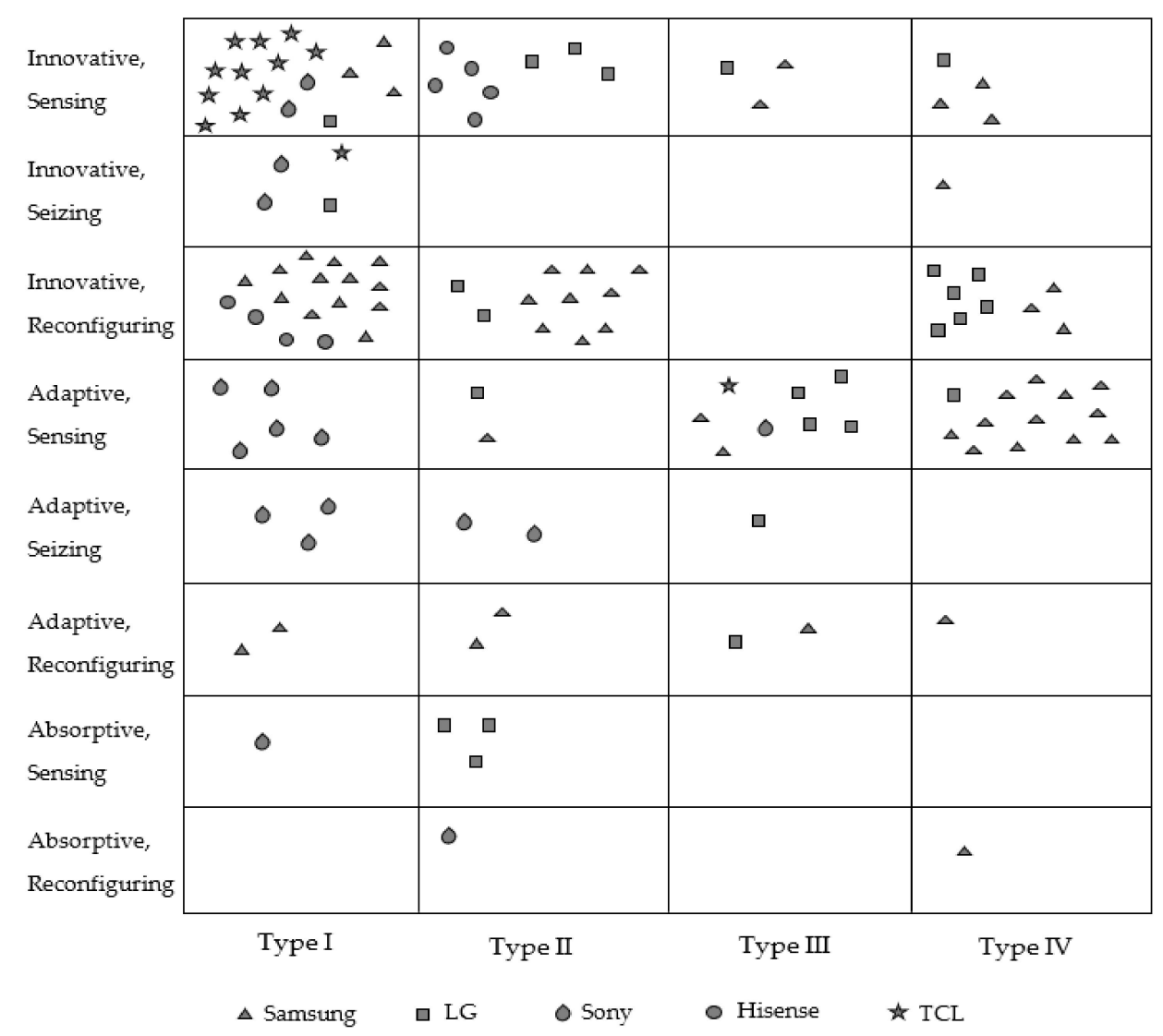

Figure 10. Dynamic capabilities and ecopreneurship types according to events in Appendix A.

Table 2. Research results of suggested propositions.

\section{Proposition}

1a

$1 b$

$2 b$

\section{Research Results}

Cases indicated that external stimuli, such as environmental regulations and consumer demand, trigger eco-innovation (evidence categories S2-6, S11, S12, L2, L7, SN2-4, SN6, T4).

A company's intention to reduce environmental impact and interest in environmental contribution drive eco-innovation actions (evidence categories S2, S6, S9, L2, L4, L5, L7-9, H1-3, T4).

The results indicate that a company's micro-level DC influences its formation of meso-level DC (evidence categories L2, L3, L4, L7-9, SN2-6, H2, H3, T1-3).

The cases showed that the combination of micro- and meso-level DC helps companies to create and capture value (evidence categories S2, S6, S7, S9-11, L3-6, L8, L9, SN2-6, T1, T2).

Companies showed various types of ecopreneurship according to various types of DC.

A company's type III ecopreneurship is mostly driven by environmental regulations, verifying Proposition $3 a$ (evidence categories S12, L2, L7, SN6, T4).

The results indicate that companies in the digital TV industry try to achieve a competitive position through technology push (evidence categories S8-S11, S14, L9, SN1-SN4, SN7, H1, T1-T3).

Features such as off-grid TVs and e-waste recycling programs indicate that some eco-innovation focuses more on complying with requirements or social contributions than gaining competitive advantage (evidence categories S12, S13, L2, L7, L8, SN6, T4).

A company's eco-innovation is driven by the goal of meeting consumer expectations and subsequently achieving competitiveness in the market (evidence categories S2-S6, L3-5).

Type I and II ecopreneurship show that companies pursue eco-innovation to satisfy consumer demand and respond to technology obsolescence (evidence categories S1, S7-S11, S14, S15, L1, L6, L9, SN1-SN5, SN7, H1, T1-T3). 
Based on the case study results of five established companies, we identified three ways of contributing to the CE through ecopreneurship in the digital TV industry: a technologyoriented strategy based on reconfiguring and innovative capabilities, a market-oriented strategy based on sensing and innovative capabilities, and an adaptive follower strategy based on sensing and adaptive capabilities.

First, Samsung and LG showed a technology-oriented strategy based on their strong reconfiguring and innovative capabilities. Samsung and LG contribute to the formation of a CE in the digital TV industry by introducing innovative outputs such as new technologies and functions to the market by reconfiguring their resource base, including tangible, intangible, and organizational capabilities [105]. For example, Samsung provides energysaving functions in their TVs and uses eco-friendly materials, such as recycled materials and materials free of hazardous substances. Moreover, Samsung enhances resource efficiency by increasing the lifespan of products, and reduces the negative impact on the environment by providing an e-waste collection and recycling program. Similar to Samsung, LG also uses eco-friendly materials for its TVs, such as carbon fiber reinforced plastic (CFRP) and recycled materials, and reduces energy consumption by using energy-saving technologies and functions. In order to enhance resource efficiency, LG uses various methods, such as using fewer screws in part connections and reducing form factor size and weight.

Second, as latecomers to the digital TV industry, Hisense and TCL utilize a marketoriented strategy by leveraging sensing and innovative capabilities. These companies reduce the energy consumption of TV displays by using local dimming technology, which many companies also use in their TVs; however, TCL differentiated itself by offering the mini-LED for the first time in the industry. While Hisense's contribution to the CE is limited to reducing energy with local dimming, TCL tries to reduce the use of hazardous substances by utilizing cadmium-free quantum dots and offering an e-waste collection and recycling program.

Finally, Sony seems to take an adaptive follower strategy based on sensing and adaptive capabilities. Based on the analysis results, Sony showed a passive attitude toward the $\mathrm{CE}$, because events indicated that they were busy trying to provide similar functions and features to those that competitors provide. Specifically, Sony shapes its contribution to the CE by sensing market trends and introducing new features in TVs to catch market opportunities. For example, considering the energy-saving boom in the TV market, Sony introduced energy-saving technology to their products, such as the backlight master drive and presence sensor. However, it seems that Sony failed to differentiate itself, because these features were not new to consumers.

\section{Implications and Future Research}

In this study, we investigated how the ecopreneurship of companies shapes the CE as viewed through the lens of DC based on a case study of leading companies in the digital TV industry. Case study results show that companies have idiosyncratic ecopreneurship in connection with their business focus and unique dynamic capabilities. Based on the analysis results, we identified three ways that companies in the TV market contribute to the $\mathrm{CE}$ and future research agendas: technology- and market-oriented strategies, and adaptive follower strategy. Since the core goal of ecopreneurship and eco-innovation for companies is to gain profits, we derived managerial implications based on the analysis results with three points:

First, the results indicate that most leading digital TV companies approach the CE seriously by designing their business strategies in consideration of their contribution to the CE. The technology- and market-oriented strategies discussed in Section 5.3 show how established companies attract consumers who are "environmentally conscious" while meeting social needs such as environmental regulations. Environmental regulations pose hurdles to companies, but once they enter into the market, these only act as basic requirements. Therefore, companies position themselves in the market based on their various types of DC to differentiate themselves from competitors. This indicates that once they 
fulfill the requirements of environmental regulations and related technology standards, it is important for companies to strategically position themselves based on considering their DC.

Second, TCL's mini-LED technology shows us that a latecomer can expand its market share competitively by implementing type I ecopreneurship, which is a combination of market pull and technology push strategies. New competition facilitates the introduction of new technological trends in the market while pushing companies to take one step further by developing eco-friendly technologies or features in order to sustain or take up a competitive position. Therefore, late entrants can leapfrog ahead of rivals through ecopreneurship while contributing to reaching a CE. Overall, the first two points highlight that a company's contribution to the $\mathrm{CE}$ is mostly a by-product of ecopreneurship with a focus on acquiring competitiveness in the market.

Finally, the form of each company's contribution to the CE depends on a combination of their micro- and meso-level DC. The analysis results show that a company's contribution to the $\mathrm{CE}$ is affected by micro-level dynamic capabilities: how it senses market changes and consumer needs (sensing), whether it has the ability to realize consumer's desired features (seizing), and how it adjusts its tangible and intangible resources to create and capture opportunity (reconfiguring). Based on micro-level DC, meso-level DC determines the major direction of how companies respond to challenges related to reducing negative environmental impact. For example, a company could adopt and apply existing technology from other companies by entering into a license (absorptive capability), or it could adjust the scope of business according to the changing market environment (adaptive capability). Considering this, companies, that wish to utilize ecopreneurship in connection with their core business need to carefully examine their micro- and meso-level DC. Conversely, this suggests that companies can analyze a competitor's DC and use it to their own advantage.

Based on the analysis results, we identified a future research agenda for in-depth investigation of the ecopreneurship of companies, with eco-innovation as part of extending our research results. First, further study could focus on other products in order to examine whether the ecopreneurship types we found in this study also apply to products other than TVs. This would confirm whether the four types of ecopreneurship also apply to other markets in the electronics industry, such as refrigerators and air-conditioners. Moreover, this will help us to understand the unique characteristics of ecopreneurship in the electronics industry. Second, a study investigating the common dynamic capabilities among leading companies is encouraged. The case study results show the existence of dynamic capabilities that leading companies commonly exhibit. A further study on common dynamic capabilities could explain the common traits that leading companies share, and possibly discover critical factors for acquiring market competitiveness.

Author Contributions: Conceptualization, S.M.; methodology, S.M.; software, S.M.; validation, S.M. and H.L.; formal analysis, S.M.; investigation, S.M.; data curation, S.M.; writing—original draft preparation, S.M.; writing—review and editing, H.L.; visualization, S.M.; supervision, H.L.; project administration, S.M. All authors have read and agreed to the published version of the manuscript.

Funding: This work was supported by a National Research Foundation Korea (NRF) grant, funded by the Korean government (MSIT) (No. 2018R1D1A1B07050139).

Institutional Review Board Statement: Not applicable.

Informed Consent Statement: Not applicable.

Conflicts of Interest: The authors declare that they have no conflict of interest.

\section{Appendix A}

Descriptions consist of core phrases from documents. 
Table A1. Summary of Samsung Case.

\begin{tabular}{|c|c|c|c|c|}
\hline Event No. & $\begin{array}{c}\text { Evidence Category } \\
\text { (Ecopreneurship Type) }\end{array}$ & Description & Source & Dynamic Capabilities \\
\hline 1 & $\begin{array}{c}\text { S1 } \\
\text { (Type II) }\end{array}$ & $\begin{array}{l}\text { Ambient mode also increases the QLED TV's } \\
\text { operation efficiency significantly with } \\
\text { energy-saving functions that turn off the screen } \\
\text { if users are not nearby. With an auto-dimming } \\
\text { sensor, the TV's brightness and color can be } \\
\text { adjusted according to the viewing environment. }\end{array}$ & $\begin{array}{l}\text { Samsung } \\
\text { (2018) }\end{array}$ & $\begin{array}{l}\text { Innovative, } \\
\text { Reconfiguring }\end{array}$ \\
\hline 2 & $\begin{array}{c}\text { S1 } \\
\text { (Type II) }\end{array}$ & $\begin{array}{l}\text { Eco ambient light sensor technology adjusts the } \\
\text { brightness of backlighting according to the } \\
\text { brightness around a product. The sensor } \\
\text { installed in an LED TV saves energy } \\
\text { consumption by as much as 53\%. } \\
\text { Ambient mode is a new feature, exclusive to }\end{array}$ & $\begin{array}{l}\text { CSR report } \\
\text { (2013) }\end{array}$ & $\begin{array}{l}\text { Innovative, } \\
\text { Reconfiguring }\end{array}$ \\
\hline 3 & $\begin{array}{c}\text { S1 } \\
\text { (Type II) }\end{array}$ & $\begin{array}{l}\text { Samsung's QLED TVs, that fills the TV screen } \\
\text { when you're not watching TV. The idea is that } \\
\text { instead of a big black rectangle in the middle of } \\
\text { the living room, you get something else. }\end{array}$ & $\begin{array}{l}\text { CNET } \\
(2018)\end{array}$ & $\begin{array}{l}\text { Innovative, } \\
\text { Reconfiguring }\end{array}$ \\
\hline 4 & $\begin{array}{c}\text { S1 } \\
\text { (Type II) }\end{array}$ & $\begin{array}{l}\text { Q70 includes ambient mode, which is like a } \\
\text { screensaver for when you're not watching TV. } \\
\text { Instead of a dead black rectangle when turned }\end{array}$ & $\begin{array}{l}\text { CNET } \\
(2019)\end{array}$ & $\begin{array}{l}\text { Innovative, } \\
\text { Reconfiguring }\end{array}$ \\
\hline 5 & $\begin{array}{c}\text { S1 } \\
\text { (Type II) }\end{array}$ & $\begin{array}{c}\text { off, the TV can be set up to show information } \\
\text { like news, weather, and traffic, or even play } \\
\text { music with various artful skins. }\end{array}$ & $\begin{array}{l}\text { CNET } \\
(2018)\end{array}$ & $\begin{array}{l}\text { Innovative, } \\
\text { Reconfiguring }\end{array}$ \\
\hline 6 & $\begin{array}{c}\text { S1 } \\
\text { (Type II) }\end{array}$ & $\begin{array}{l}\text { The Wall Luxury incorporates design-centric } \\
\text { features from other Samsung TVs. Like the } \\
\text { Frame, the Wall is not meant to be turned off. } \\
\text { Instead, Samsung says, it changes "into a } \\
\text { digital canvas best matching the owner's } \\
\text { interior needs and personal mood." }\end{array}$ & $\begin{array}{l}\text { CNET } \\
(2019)\end{array}$ & $\begin{array}{l}\text { Innovative, } \\
\text { Reconfiguring }\end{array}$ \\
\hline 7 & $\begin{array}{c}\text { S2 } \\
\text { (Type IV) }\end{array}$ & $\begin{array}{l}\text { In 2005, Samsung's Environment Analysis Lab } \\
\text { was established to put in place a system that } \\
\text { keeps track of whether hazardous substances } \\
\text { are included or not in a product's development } \\
\text { process, from specific parts and components } \\
\text { through to completed products. }\end{array}$ & $\begin{array}{l}\text { Samsung } \\
\text { (2019) }\end{array}$ & $\begin{array}{c}\text { Adaptive, } \\
\text { Reconfiguring }\end{array}$ \\
\hline 8 & $\begin{array}{c}\text { S2 } \\
\text { (Type IV) }\end{array}$ & $\begin{array}{l}\text { Only cadmium-free materials were used in } \\
\text { Samsung's SUHD TVs. This means no heavy } \\
\text { metals were utilized in the construction of these } \\
\text { products. }\end{array}$ & $\begin{array}{l}\text { Samsung } \\
\text { (2016) }\end{array}$ & $\begin{array}{l}\text { Innovative, } \\
\text { Reconfiguring }\end{array}$ \\
\hline 9 & $\begin{array}{c}\text { S2 } \\
\text { (Type IV) }\end{array}$ & $\begin{array}{l}\text { We review our suppliers based on ISO } 14001 \\
\text { certification status and their use of hazardous } \\
\text { substances in producing components in order } \\
\text { to ensure that our products are completely free } \\
\text { from any harmful substances. }\end{array}$ & $\begin{array}{l}\text { Samsung } \\
\quad(2017)\end{array}$ & Adaptive, Sensing \\
\hline 10 & $\begin{array}{c}\text { S2 } \\
\text { (Type IV) }\end{array}$ & $\begin{array}{l}\text { New regulations were introduced in South } \\
\text { America and Middle East nations, while Europe } \\
\text { and North America are strengthening existing } \\
\text { standards. We are monitoring changes in } \\
\text { energy-related regulations in order to devise } \\
\text { preemptive responses to cope with the changes. }\end{array}$ & $\begin{array}{l}\text { Samsung } \\
\text { (2012) }\end{array}$ & Adaptive, Sensing \\
\hline
\end{tabular}


Table A1. Cont.

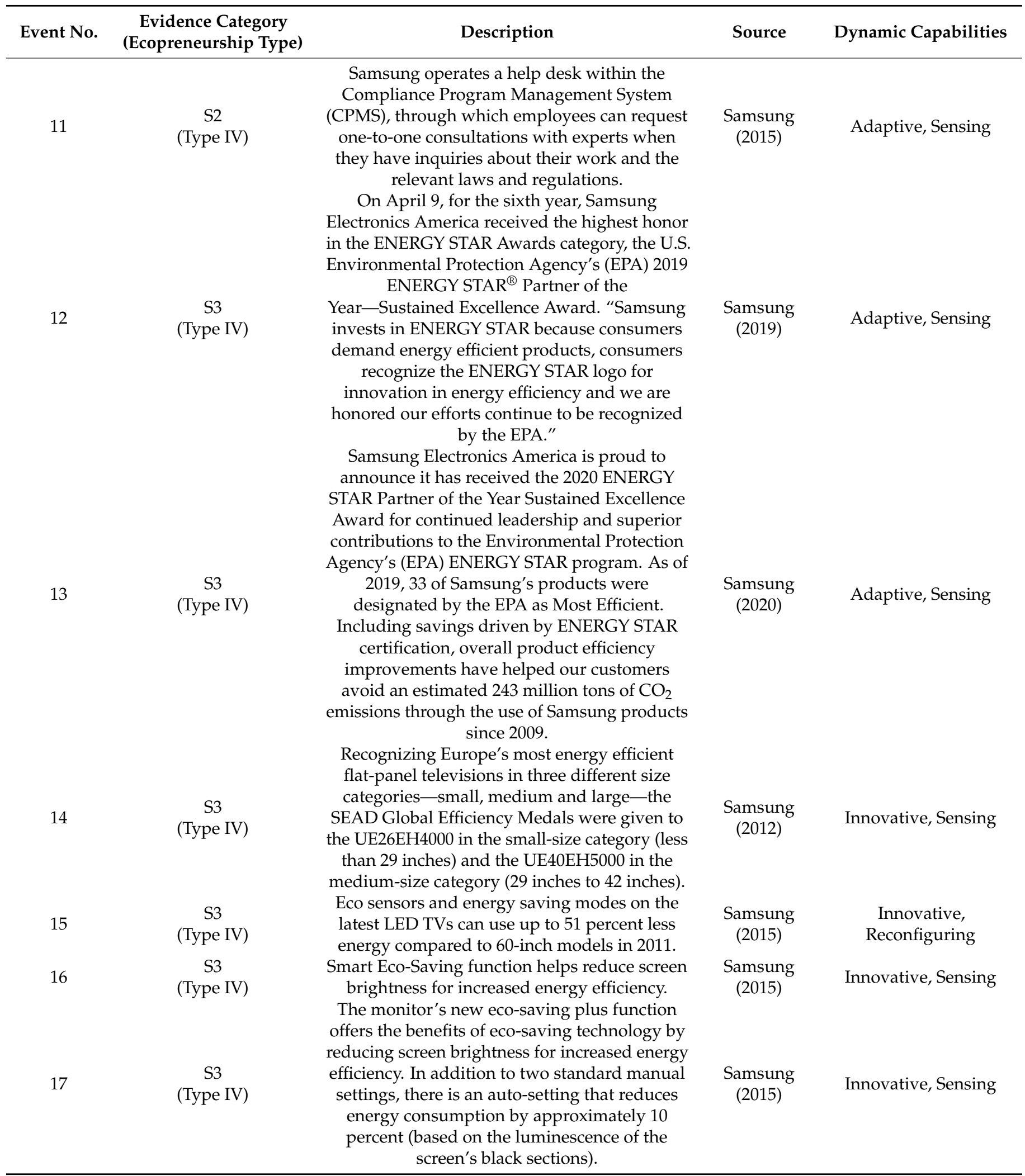


Table A1. Cont.

\begin{tabular}{|c|c|c|c|c|}
\hline Event No. & $\begin{array}{c}\text { Evidence Category } \\
\text { (Ecopreneurship Type) }\end{array}$ & Description & Source & Dynamic Capabilities \\
\hline 18 & $\begin{array}{c}\text { S3 } \\
\text { (Type IV) }\end{array}$ & $\begin{array}{l}\text { In 2011, Samsung Electronics received a total of } \\
2630 \text { product models for global Eco-Product } \\
\text { labeling, which is the highest number in the } \\
\text { electronics industry. It was granted from } 9 \\
\text { certification bodies globally that promote } \\
\text { eco-product development and green } \\
\text { procurement. }\end{array}$ & $\begin{array}{l}\text { Samsung } \\
\quad(2012)\end{array}$ & Adaptive, Sensing \\
\hline 19 & $\begin{array}{c}\text { S4 } \\
\text { (Type IV) }\end{array}$ & $\begin{array}{l}\text { In light of the accelerated implementation of } \\
\text { LED displays that offer enhanced picture } \\
\text { quality, energy efficiency, and operational } \\
\text { functionality, Samsung will work with YESCO } \\
\text { Electronics to deliver durable, long-lasting } \\
\text { displays geared for varied and extreme } \\
\text { conditions. }\end{array}$ & $\begin{array}{l}\text { Samsung } \\
\text { (2015) }\end{array}$ & $\begin{array}{c}\text { Absorptive, } \\
\text { Reconfiguring }\end{array}$ \\
\hline 20 & $\begin{array}{c}\text { S5 } \\
\text { (Type IV) }\end{array}$ & $\begin{array}{l}\text { All suppliers that provide products or } \\
\text { components to be sold by Samsung Electronics } \\
\text { are subject to Eco-Partner certification. We } \\
\text { grant certification by assessing their compliance } \\
\text { with our standards for control of substances } \\
\text { used in products and the suppliers' } \\
\text { environmental quality management system. } \\
\text { Achieved recognition in } 9 \text { countries including }\end{array}$ & $\begin{array}{l}\text { Samsung } \\
\text { (n.d.) }\end{array}$ & Adaptive, Sensing \\
\hline 21 & $\begin{array}{c}\text { S6 } \\
\text { (Type IV) }\end{array}$ & $\begin{array}{l}\text { Korea, USA, and various European countries, } \\
\text { recognized by global standardization } \\
\text { organizations including UL and Canadian CSA } \\
\text { Group. }\end{array}$ & $\begin{array}{l}\text { Samsung } \\
\text { (2019) }\end{array}$ & Adaptive, Sensing \\
\hline 22 & $\begin{array}{c}\text { S6 } \\
\text { (Type IV) }\end{array}$ & $\begin{array}{l}\text { Samsung's SmartThings Energy, part of } \\
\text { Samsung's IoT platform SmartThings, is a } \\
\text { service that allows users to easily and } \\
\text { comprehensively monitor their home's } \\
\text { electricity consumption. }\end{array}$ & $\begin{array}{l}\text { Samsung } \\
(2020)\end{array}$ & Adaptive, Sensing \\
\hline 23 & $\begin{array}{c}\text { S6 } \\
\text { (Type IV) }\end{array}$ & $\begin{array}{l}\text { ECOS, the Energy Cost Optimization Solution } \\
\text { powered by Samsung, is designed to empower } \\
\text { customers to use the SmartThings IoT platform } \\
\text { to its full environmental potential. }\end{array}$ & $\begin{array}{l}\text { Samsung } \\
\text { (2015) }\end{array}$ & Adaptive, Sensing \\
\hline 24 & $\begin{array}{c}\text { S6 } \\
\text { (Type IV) }\end{array}$ & $\begin{array}{l}\text { To help businesses conserve energy, resources, } \\
\text { and costs, the UE } 850 \text { is constructed using } 30 \\
\text { percent recycled plastic and a PVC-free body. }\end{array}$ & $\begin{array}{l}\text { Samsung } \\
\quad(2015)\end{array}$ & $\begin{array}{l}\text { Innovative, } \\
\text { Reconfiguring }\end{array}$ \\
\hline 25 & $\begin{array}{c}\text { S6 } \\
\text { (Type IV) }\end{array}$ & $\begin{array}{l}\text { Samsung's products were recognized by } \\
\text { international certification organization TUV } \\
\text { Rheinland with industry-leading validation for } \\
\text { products' eco-friendliness and high, outdoor } \\
\text { visibility. TUV Rheinland validated the } 27 \text {-inch } \\
\text { LCD monitor's zero-watt power consumption, } \\
\text { making the Samsung Eco-Power Off function } \\
\text { the world's first } 0.00 \mathrm{~W} \text { power consumption } \\
\text { technology. }\end{array}$ & $\begin{array}{l}\text { Samsung } \\
\quad(2015)\end{array}$ & Innovative, Seizing \\
\hline 26 & $\begin{array}{c}\text { S6 } \\
\text { (Type IV) }\end{array}$ & $\begin{array}{l}\text { Another CES announcement fleshed out today, } \\
\text { the TV can act as a hub to control lights, } \\
\text { thermostats, security cameras, smart appliances, } \\
\text { and more, right on-screen. }\end{array}$ & $\begin{array}{l}\text { CNET } \\
(2018)\end{array}$ & Adaptive, Sensing \\
\hline
\end{tabular}


Table A1. Cont.

\begin{tabular}{|c|c|c|c|c|}
\hline Event No. & $\begin{array}{c}\text { Evidence Category } \\
\text { (Ecopreneurship Type) }\end{array}$ & Description & Source & Dynamic Capabilities \\
\hline 27 & $\begin{array}{c}\text { S6 } \\
\text { (Type IV) }\end{array}$ & $\begin{array}{l}\text { A big-screen app lets the TV serve as the hub to } \\
\text { control SmartThings smart home devices, from } \\
\text { lights to thermostats to security cameras. You } \\
\text { can receive notifications on the TV, for example, } \\
\text { when a load of laundry is done. }\end{array}$ & $\begin{array}{l}\text { CNET } \\
(2018)\end{array}$ & Adaptive, Sensing \\
\hline 28 & $\begin{array}{c}\text { S7 } \\
\text { (Type II) }\end{array}$ & $\begin{array}{l}\text { The feature mentioned in the article is called } \\
\text { "motion lighting," which reduces power } \\
\text { consumption by reducing screen brightness } \\
\text { when the picture on the screen is in motion. It is } \\
\text { a standard out-of-the-box feature, which is } \\
\text { switched on when the customer takes delivery } \\
\text { of their TV, and remains on whenever the } \\
\text { customer chooses to watch their TV in Standard } \\
\text { viewing mode. }\end{array}$ & $\begin{array}{l}\text { Samsung } \\
\text { (2015) }\end{array}$ & $\begin{array}{l}\text { Innovative, } \\
\text { Reconfiguring }\end{array}$ \\
\hline 29 & $\begin{array}{c}\text { S7 } \\
\text { (Type II) }\end{array}$ & $\begin{array}{l}\text { The Frame, which transforms any living room } \\
\text { into an aesthetically pleasing gallery, along } \\
\text { with other diverse accessories equipped for } \\
\text { each product line-up will enable us to cater } \\
\text { diverse consumer preferences. }\end{array}$ & $\begin{array}{l}\text { Samsung } \\
\text { (2017) }\end{array}$ & $\begin{array}{c}\text { Adaptive, } \\
\text { Reconfiguring }\end{array}$ \\
\hline 30 & $\begin{array}{c}\text { S7 } \\
\text { (Type II) }\end{array}$ & $\begin{array}{l}\text { "Motion lighting is not a setting that only } \\
\text { activates during compliance testing," the South } \\
\text { Korean company said in a blog post. "On the } \\
\text { contrary, it is a default setting which works } \\
\text { both in the lab and at home, delivering energy } \\
\text { savings and helping us to reduce our } \\
\text { environmental impact." }\end{array}$ & $\begin{array}{l}\text { CNET } \\
(2015)\end{array}$ & $\begin{array}{c}\text { Innovative, } \\
\text { Reconfiguring }\end{array}$ \\
\hline 31 & $\begin{array}{c}\text { S7 } \\
\text { (Type II) }\end{array}$ & $\begin{array}{l}\text { Instead of turning off like a normal TV, leaving } \\
\text { a blank black rectangle on the wall, The Frame } \\
\text { is designed to always show its picture when } \\
\text { someone is in the room. It uses a motion sensor } \\
\text { that keeps the image onscreen as long as it } \\
\text { senses movement. When there's no motion } \\
\text { after a while, the screen goes blank, saving } \\
\text { power. When the screen is on and showing art, } \\
\text { an ambient light sensor matches its brightness } \\
\text { level to the room. }\end{array}$ & $\begin{array}{l}\text { CNET } \\
(2017)\end{array}$ & $\begin{array}{c}\text { Adaptive, } \\
\text { Reconfiguring }\end{array}$ \\
\hline 32 & $\begin{array}{c}\text { S7 } \\
\text { (Type II) }\end{array}$ & $\begin{array}{l}\text { It's a smart TV built to look like a picture frame. } \\
\text { It comes with a black bezel (other colors are } \\
\text { available separately), a no-gap wall mount, and } \\
\text { a collection of } 100 \text { works of art, which will } \\
\text { show onscreen when the TV isn't doing TV } \\
\text { things. You can also upload your own photos. }\end{array}$ & $\begin{array}{l}\text { CNET } \\
(2019)\end{array}$ & $\begin{array}{l}\text { Innovative, } \\
\text { Reconfiguring }\end{array}$ \\
\hline 33 & $\begin{array}{c}\text { S8 } \\
\text { (Type I) }\end{array}$ & $\begin{array}{l}\text { The LED TV UN46B7000WF boasts impressive } \\
\text { reductions in power consumption and standby } \\
\text { power. In comparison with LCD TV, the } \\
\text { product consumes } 43 \% \text { less power while in use } \\
\text { and requires } 86 \% \text { less standby power. }\end{array}$ & $\begin{array}{l}\text { Samsung } \\
\quad(2010)\end{array}$ & Innovative, Sensing \\
\hline 34 & $\begin{array}{c}\text { S8 } \\
\text { (Type I) }\end{array}$ & $\begin{array}{l}\text { It is the least-expensive Samsung QLED TV to } \\
\text { feature full-array local dimming (FALD), which } \\
\text { gives it an excellent picture. }\end{array}$ & $\begin{array}{l}\text { CNET } \\
(2019)\end{array}$ & $\begin{array}{l}\text { Innovative, } \\
\text { Reconfiguring }\end{array}$ \\
\hline 35 & $\begin{array}{c}\text { S8 } \\
\text { (Type I) }\end{array}$ & $\begin{array}{l}\text { Under the hood, the } \mathrm{S} 9 \text { also differentiates itself } \\
\text { from other } 4 \mathrm{~K} \text { TVs, offering the rare full-array } \\
\text { local dimming backlight, which can improve its } \\
\text { picture quality compared with their edge-lit } \\
\text { local dimming configurations. }\end{array}$ & $\begin{array}{l}\text { CNET } \\
(2014)\end{array}$ & $\begin{array}{l}\text { Innovative, } \\
\text { Reconfiguring }\end{array}$ \\
\hline
\end{tabular}


Table A1. Cont.

\begin{tabular}{|c|c|c|c|c|}
\hline Event No. & $\begin{array}{c}\text { Evidence Category } \\
\text { (Ecopreneurship Type) }\end{array}$ & Description & Source & Dynamic Capabilities \\
\hline 36 & $\begin{array}{c}\text { S8 } \\
\text { (Type I) }\end{array}$ & $\begin{array}{l}\text { The biggest news for video quality fans is the } \\
\text { confirmation that the two highest-end models } \\
\text { will get full-array local dimming (FALD) } \\
\text { backlights, which could help them better } \\
\text { compete against OLED, the incumbent picture } \\
\text { quality champ. }\end{array}$ & $\begin{array}{l}\text { CNET } \\
(2018)\end{array}$ & $\begin{array}{l}\text { Innovative, } \\
\text { Reconfiguring }\end{array}$ \\
\hline 37 & $\begin{array}{c}\text { S9 } \\
\text { (Type I) }\end{array}$ & $\begin{array}{l}\text { As the name suggests, MicroLED uses millions } \\
\text { of individual teeny, tiny LEDs to create its } \\
\text { image. It promises all of the great picture } \\
\text { quality of OLED (perfect black levels, improved } \\
\text { off-axis viewing) along with superior } \\
\text { brightness and less of a propensity for burn-in. }\end{array}$ & $\begin{array}{l}\text { CNET } \\
(2019)\end{array}$ & $\begin{array}{c}\text { Innovative, } \\
\text { Reconfiguring }\end{array}$ \\
\hline 38 & $\begin{array}{c}\text { S9 } \\
\text { (Type I) }\end{array}$ & $\begin{array}{l}\text { A report out of Korea names Samsung's Micro } \\
\text { LED as one contender. The technology uses an } \\
\text { array of very small, pixel-sized light-emitting } \\
\text { diodes to produce an image, doing away with } \\
\text { the LCD panel entirely. It can get very bright } \\
\text { and can turn each LED off individually, so it } \\
\text { can produce absolute black and an infinite } \\
\text { contrast ratio (just like OLED). Samsung has } \\
\text { shown it before in the form of Cinema Screen } \\
\text { for the commercial market, but the report says } \\
\text { it will appear in a 150-inch TV at the show, and } \\
\text { be commercialized later in } 2018 \text {. }\end{array}$ & $\begin{array}{l}\text { CNET } \\
(2017)\end{array}$ & $\begin{array}{l}\text { Innovative, } \\
\text { Reconfiguring }\end{array}$ \\
\hline 39 & $\begin{array}{c}\text { S9 } \\
\text { (Type I) }\end{array}$ & $\begin{array}{l}\text { Unlike traditional LED-based LCD TVs, which } \\
\text { use a liquid crystal layer and an LED backlight, } \\
\text { MicroLED uses an array of millions of } \\
\text { individual, tiny LEDs to create the image. } \\
\text { Because each LED can turn on or off } \\
\text { individually, MicroLED has the potential for } \\
\text { infinite contrast, just like OLED TVs. The Wall } \\
\text { can achieve a searing 2000-nit brightness, } \\
\text { higher than any LED LCD we've tested, and the } \\
\text { combination should produce breathtaking pop, } \\
\text { especially for HDR sources. }\end{array}$ & $\begin{array}{l}\text { CNET } \\
(2018)\end{array}$ & $\begin{array}{l}\text { Innovative, } \\
\text { Reconfiguring }\end{array}$ \\
\hline 40 & $\begin{array}{c}\text { S9 } \\
\text { (Type I) }\end{array}$ & $\begin{array}{l}\text { The first new screen technology in a decade, } \\
\text { MicroLED utilizes millions of tiny, inorganic } \\
\text { LEDs packed together to create the image. It } \\
\text { has the potential for the same perfect black } \\
\text { levels as OLED with no danger of burn-in. It } \\
\text { can deliver higher brightness than any current } \\
\text { display technology, wide-gamut excellent color, } \\
\text { and doesn't suffer the viewing angle and } \\
\text { uniformity issues of LCD. }\end{array}$ & $\begin{array}{l}\text { CNET } \\
(2019)\end{array}$ & $\begin{array}{l}\text { Innovative, } \\
\text { Reconfiguring }\end{array}$ \\
\hline 41 & $\begin{array}{c}\text { S10 } \\
\text { (Type I) }\end{array}$ & $\begin{array}{l}\text { OLED promises better picture quality than } \\
\text { plasma, better energy efficiency than LED LCD, } \\
\text { while being both thinner and lighter. }\end{array}$ & $\begin{array}{l}\text { CNET } \\
(2013)\end{array}$ & Innovative, Sensing \\
\hline 42 & $\begin{array}{c}\text { S11 } \\
\text { (Type I) }\end{array}$ & $\begin{array}{c}\text { Similar to its 8K TV counterpart, the QLED 8K } \\
\text { display delivers enhanced black color } \\
\text { presentation through local dimming and } \\
\text { Quantum Light Control. }\end{array}$ & $\begin{array}{l}\text { Samsung } \\
\quad(2019)\end{array}$ & $\begin{array}{c}\text { Adaptive, } \\
\text { Reconfiguring }\end{array}$ \\
\hline
\end{tabular}


Table A1. Cont.

\begin{tabular}{|c|c|c|c|c|}
\hline Event No. & $\begin{array}{c}\text { Evidence Category } \\
\text { (Ecopreneurship Type) }\end{array}$ & Description & Source & Dynamic Capabilities \\
\hline 43 & $\begin{array}{c}\text { S11 } \\
\text { (Type I) }\end{array}$ & $\begin{array}{l}\text { Quantum dots enable much brighter color, } \\
\text { meaning that you have both efficiency and } \\
\text { improved color gamut. This means that } \\
\text { quantum dot televisions allow for more realistic } \\
\text { and lifelike content so that viewers can more } \\
\text { easily recognize the dream of the content } \\
\text { creator and all the details he or she is trying to } \\
\text { show. }\end{array}$ & $\begin{array}{l}\text { Samsung } \\
\text { (2016) }\end{array}$ & $\begin{array}{l}\text { Innovative, } \\
\text { Reconfiguring }\end{array}$ \\
\hline 44 & $\begin{array}{c}\text { S11 } \\
\text { (Type I) }\end{array}$ & $\begin{array}{l}\text { With SUHD TVs that feature quantum dot } \\
\text { technology, however, Samsung has an answer } \\
\text { that allows TV sets to hit those brightness levels } \\
\text { of up to } 1000 \text { nits without the pain points. This } \\
\text { is in part thanks to the photo-active property of } \\
\text { quantum dots, which makes them very } \\
\text { energy-efficient. Samsung was actually able to } \\
\text { improve the overall energy efficiency of its } 2016 \\
\text { SUHD TVs while enabling the set to hit } 1000 \\
\text { nits. }\end{array}$ & $\begin{array}{l}\text { Samsung } \\
\quad(2016)\end{array}$ & $\begin{array}{l}\text { Innovative, } \\
\text { Reconfiguring }\end{array}$ \\
\hline 45 & $\begin{array}{c}\text { S11 } \\
\text { (Type I) }\end{array}$ & $\begin{array}{l}\text { Samsung's quantum dots, however, are } \\
\text { cadmium-free. They're based on indium (In) } \\
\text { instead. After much research and development, } \\
\text { Samsung is currently the only company that } \\
\text { produces cadmium-free quantum dot displays. } \\
\text { Samsung's quantum dots are also durable. } \\
\text { Being an inorganic compound, quantum dots } \\
\text { are more resistant to oxidation than organic } \\
\text { substances. Samsung also applies a quad-layer } \\
\text { coat to its quantum dots to ensure the quantum } \\
\text { dot display is durable and kept stable over } \\
\text { years of time. The result: a fantastic display that } \\
\text { keeps its picture quality year after year. }\end{array}$ & $\begin{array}{l}\text { Samsung } \\
\quad(2016)\end{array}$ & $\begin{array}{l}\text { Innovative, } \\
\text { Reconfiguring }\end{array}$ \\
\hline 46 & $\begin{array}{c}\text { S11 } \\
\text { (Type I) }\end{array}$ & $\begin{array}{l}\text { In addition, the QLED TV's inorganic quantum } \\
\text { dot technology is free from burn-in, letting } \\
\text { users appreciate Ambient Mode as much as } \\
\text { they want without seeing afterimages, even } \\
\text { after a static picture has remained on screen for } \\
\text { an extended length of time. }\end{array}$ & $\begin{array}{l}\text { Samsung } \\
\text { (2018) }\end{array}$ & $\begin{array}{l}\text { Innovative, } \\
\text { Reconfiguring }\end{array}$ \\
\hline 47 & $\begin{array}{c}\text { S11 } \\
\text { (Type I) }\end{array}$ & $\begin{array}{l}\text { In early summer 2018, the Q9 and its main } \\
\text { competitor, LG's C8 OLED TV, cost about the } \\
\text { same, while the Q8 is a significant chunk of } \\
\text { change cheaper. That makes it a solid } \\
\text { alternative for the high-end TV shopper who's } \\
\text { wary of OLED burn-in or needs a 75-inch TV. }\end{array}$ & $\begin{array}{l}\text { CNET } \\
(2018)\end{array}$ & $\begin{array}{l}\text { Innovative, } \\
\text { Reconfiguring }\end{array}$ \\
\hline 48 & $\begin{array}{c}\text { S11 } \\
\text { (Type I) }\end{array}$ & $\begin{array}{l}\text { The similar to rival LG, the secret sauce is } \\
\text { 'quantum-dot' technology, or what Samsung is } \\
\text { calling "proprietary cadmium-free nano-crystal } \\
\text { technology." These are nano-crystals mixed } \\
\text { with the blue LEDs that form the backlights of } \\
\text { these TVs. The crystals emit specific } \\
\text { wavelengths of red and green, which, combined } \\
\text { with the blue LEDs, can make for both brighter } \\
\text { images and a wider color gamut than current } \\
\text { backlighting technology. }\end{array}$ & $\begin{array}{l}\text { CNET } \\
(2015)\end{array}$ & $\begin{array}{l}\text { Innovative, } \\
\text { Reconfiguring }\end{array}$ \\
\hline
\end{tabular}


Table A1. Cont.

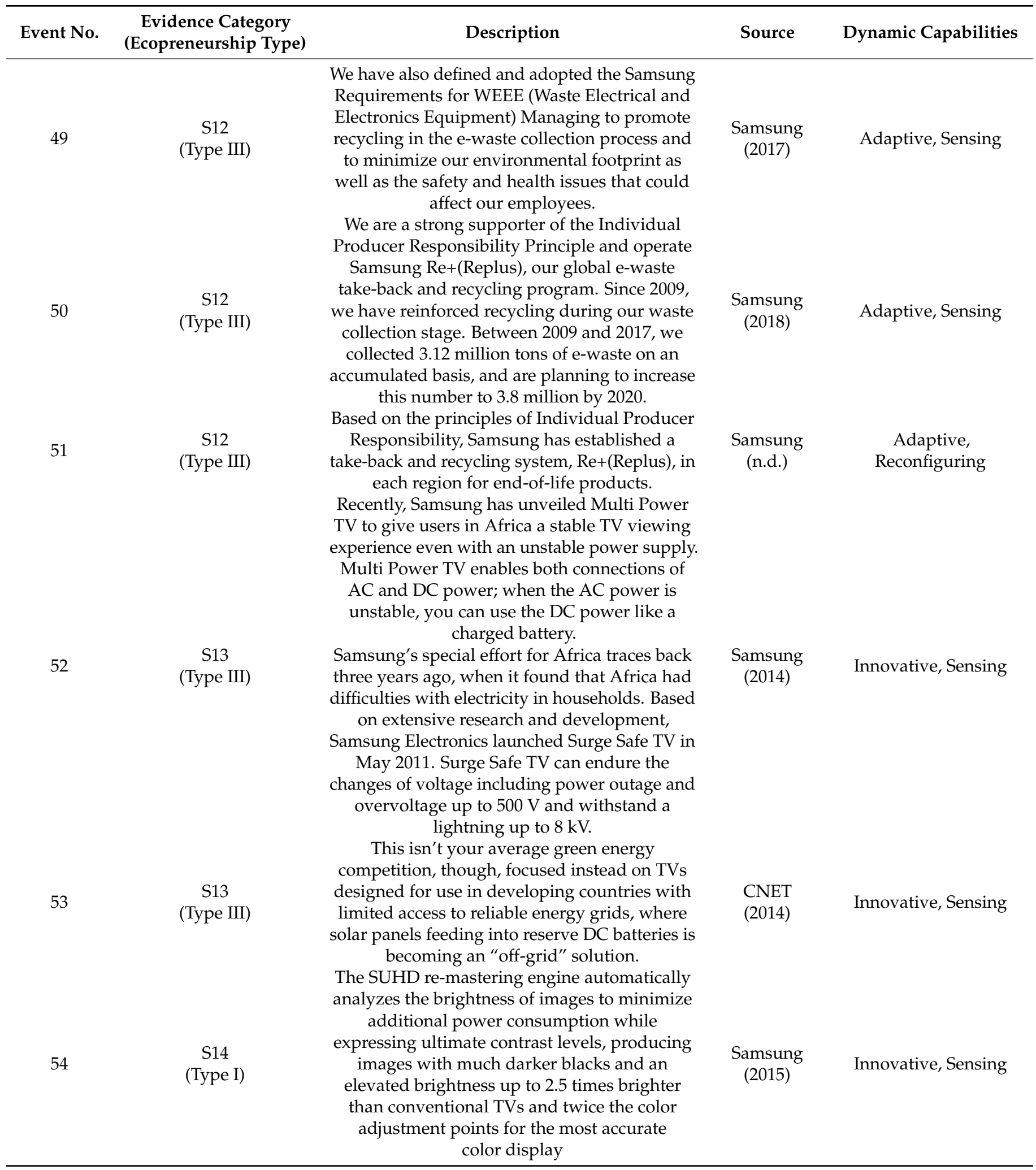


Table A1. Cont.

\begin{tabular}{|c|c|c|c|c|}
\hline Event No. & $\begin{array}{c}\text { Evidence Category } \\
\text { (Ecopreneurship Type) }\end{array}$ & Description & Source & Dynamic Capabilities \\
\hline 55 & $\begin{array}{c}\text { S14 } \\
\text { (Type I) }\end{array}$ & $\begin{array}{l}\text { Samsung's upcoming lineup of Smart TVs, as } \\
\text { well as its } 2016 \text { series of high-end, } 4 \text { K-resolution } \\
\text { LCD TVs (known as SUHD TVs) will be } \\
\text { compatible with the company's Internet of } \\
\text { Things platform called SmartThings, the South } \\
\text { Korean electronics giant said Tuesday. } \\
\text { By being able to connect with Samsung's smart } \\
\text { home service, you will be able to control other } \\
\text { SmartThings-compatible devices, like locks and } \\
\text { thermostats, from your TV on a single interface. }\end{array}$ & $\begin{array}{l}\text { CNET } \\
(2015)\end{array}$ & $\begin{array}{c}\text { Adaptive, } \\
\text { Reconfiguring }\end{array}$ \\
\hline 56 & $\begin{array}{c}\text { S15 } \\
\text { (Type II) }\end{array}$ & $\begin{array}{l}\text { The UE850's Off Timer Plus function reduces } \\
\text { power consumption and enables power-off } \\
\text { scheduling, while the Smart Eco-Saving } \\
\text { function helps reduce screen brightness for } \\
\text { increased energy efficiency. }\end{array}$ & $\begin{array}{l}\text { Samsung } \\
\text { (2015) }\end{array}$ & Adaptive, Sensing \\
\hline
\end{tabular}

Table A2. Summary of LG Case.

\begin{tabular}{|c|c|c|c|c|}
\hline $\begin{array}{l}\text { Event } \\
\text { No. }\end{array}$ & $\begin{array}{c}\text { Evidence Category } \\
\text { (Ecopreneurship Type) }\end{array}$ & Description & Source & Dynamic Capabilities \\
\hline 1 & $\begin{array}{c}\text { L1 } \\
\text { (Type II) }\end{array}$ & $\begin{array}{l}\text { Using voice commands, you can find and play } \\
\text { content, for example via streaming services, and } \\
\text { control TV settings. Combined with LG's ThinQ } \\
\text { technology, it also controls connecting to devices like } \\
\text { sound bars, switching picture modes, or turning off } \\
\text { the TV. }\end{array}$ & $\begin{array}{l}\text { CNET } \\
(2018)\end{array}$ & Absorptive, Sensing \\
\hline 2 & $\begin{array}{c}\text { L1 } \\
\text { (Type II) }\end{array}$ & $\begin{array}{c}\text { AI integration into LG's OLED TVs means you can } \\
\text { control the TV with your voice. You can ask it to play } \\
\text { your favorite show, search for a movie soundtrack or } \\
\text { check information about a cast or director. } \\
\text { Integration of Google Assistant also means you can } \\
\text { do things like check the weather, plan a vacation, or } \\
\text { use instant translation from your TV. Additionally, } \\
\text { you can connect and control all your smart home } \\
\text { devices using Google Assistant. }\end{array}$ & $\begin{array}{l}\text { CNET } \\
(2018)\end{array}$ & Absorptive, Sensing \\
\hline 3 & $\begin{array}{c}\text { L1 } \\
\text { (Type II) }\end{array}$ & $\begin{array}{l}\text { LG says users will be able to issue commands such as } \\
\text { "search for the soundtrack of this movie" or "turn off } \\
\text { the TV when this program is over". The TV's Google } \\
\text { Assistant also allows control of compatible smart } \\
\text { home devices and streaming audio products. }\end{array}$ & $\begin{array}{l}\text { CNET } \\
(2018)\end{array}$ & Absorptive, Sensing \\
\hline 4 & $\begin{array}{c}\text { L2 } \\
\text { (Type III) }\end{array}$ & $\begin{array}{l}\text { In order to eliminate risks of non-compliance with } \\
\text { environmental laws, we conduct environmental } \\
\text { status assessments at production sites, take measures } \\
\text { to correct issues identified in the assessments, and } \\
\text { monitor the progress. } \\
\text { We comply with environmental laws by installing } \\
\text { and operating pollution prevention facilities, and } \\
\text { continuously improving our environmental } \\
\text { management procedures. } \\
\text { We plan to establish legal compliance monitoring } \\
\text { systems by region, area of concern, and business site, } \\
\text { in addition to organizing regular meetings to share } \\
\text { developments regarding environmental regulations. }\end{array}$ & $\begin{array}{c}\text { LG } \\
(2019)\end{array}$ & Adaptive, Sensing \\
\hline
\end{tabular}


Table A2. Cont.

\begin{tabular}{|c|c|c|c|c|}
\hline $\begin{array}{l}\text { Event } \\
\text { No. }\end{array}$ & $\begin{array}{c}\text { Evidence Category } \\
\text { (Ecopreneurship Type) }\end{array}$ & Description & Source & Dynamic Capabilities \\
\hline 5 & $\begin{array}{c}\text { L2 } \\
\text { (Type III) }\end{array}$ & $\begin{array}{l}\text { LG Electronics complies with international } \\
\text { regulations on hazardous substances including RoHS } \\
\text { and REACH. LGE has operated a supply chain green } \\
\text { management program, Green Program Plus, to } \\
\text { monitor hazardous substances in our supply chain }\end{array}$ & $\begin{array}{l}\text { LG } \\
\text { (n.d.) }\end{array}$ & Adaptive, Sensing \\
\hline 6 & $\begin{array}{c}\text { L2 } \\
\text { (Type III) }\end{array}$ & $\begin{array}{l}\text { LG Electronics has been operating the precision } \\
\text { analysis accredited environmental testing lab for } \\
\text { hazardous substances, which is equipped with } \\
\text { ICP-OES, ICP-MS, GC-MS, UV-Vis, HPLC, VOC } \\
\text { chamber, and IC. The lab has been supporting } \\
\text { hazardous substances reduction and verification of } \\
\text { greener products via testing for high-risk materials } \\
\text { and inspecting parts and products for compliance } \\
\text { with internal limits on hazardous substances. }\end{array}$ & $\begin{array}{l}\text { LG } \\
\text { (n.d.) }\end{array}$ & Adaptive, Sensing \\
\hline 7 & $\begin{array}{c}\text { L2 } \\
\text { (Type III) }\end{array}$ & $\begin{array}{l}\text { Moreover, we are proactively replacing substances } \\
\text { that are not currently regulated but believed to be } \\
\text { hazardous, such as PVC (poly-vinyl chloride) and } \\
\text { BFRs (brominated flame retardants). As a result of } \\
\text { our ongoing R\&D effort, all our mobile phone } \\
\text { products are free of PVC and BFRs as of 2010, and } \\
\text { PVC cables in our UHD/OLED TV products have } \\
\text { been replaced with substitute materials. }\end{array}$ & $\begin{array}{c}\text { LG } \\
(2014)\end{array}$ & Adaptive, Sensing \\
\hline 8 & $\begin{array}{c}\text { L3 } \\
\text { (Type IV) }\end{array}$ & $\begin{array}{l}\text { Another accolade was bestowed on the CINEMA 3D } \\
\text { Smart TV lineup in December when the 55LA6900 } \\
\text { model earned an Environmental Product Declaration } \\
\text { (EPD) from Underwriters Laboratories Inc. The } \\
\text { 55LA6900 was singled out for its remarkable energy } \\
\text { efficiency and eco-friendly qualities. }\end{array}$ & $\begin{array}{c}\text { LG } \\
(2012)\end{array}$ & $\begin{array}{l}\text { Innovative, } \\
\text { Reconfiguring }\end{array}$ \\
\hline 9 & $\begin{array}{c}\text { L3 } \\
\text { (Type IV) }\end{array}$ & $\begin{array}{l}\text { LG Electronics (LG) announced that its CINEMA 3D } \\
\text { TV (Model 47LM7600) has been certified with the } \\
\text { Green Mark from TÜV Rheinland, one of the world's } \\
\text { first TVs to receive such recognition. } \\
\text { TÜV Rheinland, the world's leading inspection, } \\
\text { testing, and certification service provider, awards the } \\
\text { Green Mark only to products that pass } \\
\text { comprehensive tests for environmental friendliness } \\
\text { and sustainability. The tests look at energy efficiency } \\
\text { as well as the absence of hazardous chemicals. The } \\
\text { product's carbon footprint is also calculated, and } \\
\text { consideration is given to safety and social } \\
\text { compliance. }\end{array}$ & $\begin{array}{c}\text { LG } \\
(2012)\end{array}$ & $\begin{array}{l}\text { Innovative, } \\
\text { Reconfiguring }\end{array}$ \\
\hline 10 & $\begin{array}{c}\text { L3 } \\
\text { (Type IV) }\end{array}$ & $\begin{array}{l}\text { The Cinema 3D Smart TV achieved high energy } \\
\text { efficiency with Local Dimming Technology (controls } \\
\text { individual LEDs for maximum energy efficiency), } \\
\text { Smart Energy Saving Technology (reduces energy } \\
\text { consumption by adjusting to the ambient light), and } \\
\text { the placement of backlight units (minimizes the } \\
\text { number of backlight units by placing them at the } \\
\text { bottom). }\end{array}$ & $\begin{array}{c}\text { LG } \\
(2012)\end{array}$ & Innovative, Sensing \\
\hline
\end{tabular}


Table A2. Cont.

\begin{tabular}{|c|c|c|c|c|}
\hline $\begin{array}{l}\text { Event } \\
\text { No. }\end{array}$ & $\begin{array}{c}\text { Evidence Category } \\
\text { (Ecopreneurship Type) }\end{array}$ & Description & Source & Dynamic Capabilities \\
\hline 11 & $\begin{array}{c}\text { L4 } \\
\text { (Type IV) }\end{array}$ & $\begin{array}{l}\text { Further highlighting its green credentials, LG's next } \\
\text { generation TV has been placed on EPEAT's registry } \\
\text { for responsibly designed and built electronic devices. } \\
\text { EPEAT is a non-profit organization that publishes a } \\
\text { global registry of green electronic products for the } \\
\text { benefit of both consumers and manufacturers. To be } \\
\text { included in EPEAT's registry requires a product to } \\
\text { meet no less than } 24 \text { environmental criteria related to } \\
\text { energy efficiency, recyclability, packaging, longevity, } \\
\text { and reduction in the use of harmful materials. } \\
\text { The TV's bodv is constructed of carbon fiber }\end{array}$ & $\begin{array}{c}\text { LG } \\
(2013)\end{array}$ & $\begin{array}{l}\text { Innovative, } \\
\text { Reconfiguring }\end{array}$ \\
\hline 12 & $\begin{array}{c}\text { L5 } \\
\text { (Type IV) }\end{array}$ & $\begin{array}{c}\text { reinforced plastic (CFRP), a sustainable material that } \\
\text { contributes to the extreme thinness }(4.3 \mathrm{~mm}) \text { and } \\
\text { light weight }(17 \mathrm{~kg}) \text { of this stunning next generation } \\
\text { LG display. }\end{array}$ & $\begin{array}{c}\text { LG } \\
(2013)\end{array}$ & $\begin{array}{l}\text { Innovative, } \\
\text { Reconfiguring }\end{array}$ \\
\hline 13 & $\begin{array}{c}\text { L5 } \\
\text { (Type IV) }\end{array}$ & $\begin{array}{l}\text { LGE is increasing the use of recycled materials by } \\
\text { testing the product stability and quality to promote } \\
\text { the recycling of resources and improve its efficiency. } \\
\text { As a result, recycled materials are being used for our } \\
\text { washing machines, refrigerators, air solutions, } \\
\text { smartphones, TVs, and monitors. }\end{array}$ & $\begin{array}{c}\text { LG } \\
(2019)\end{array}$ & Adaptive, Sensing \\
\hline 14 & $\begin{array}{c}\text { L5 } \\
\text { (Type IV) }\end{array}$ & $\begin{array}{l}\text { The LED LCD TV 47LE } 8500 \text { received the Eco Design } \\
\text { Innovation Award at the US CES } 2010 \text { by cutting } \\
\text { resources by using less screws in part connections. }\end{array}$ & $\begin{array}{c}\text { LG } \\
(2010)\end{array}$ & $\begin{array}{c}\text { Innovative, } \\
\text { Reconfiguring }\end{array}$ \\
\hline 15 & $\begin{array}{c}\text { L5 } \\
\text { (Type IV) }\end{array}$ & $\begin{array}{l}\text { LG Electronics puts great effort into maintaining the } \\
\text { highest level of material quality and product } \\
\text { structure from the initial phase of product } \\
\text { development and collaborates with recyclers to } \\
\text { increase recyclability, ease of disassembly, and } \\
\text { product performance while reducing form factor size } \\
\text { and weight wherever possible. Based on such efforts, } \\
\text { we were able to achieve a weight reduction of } \\
\text { approximately } 9 \text { percent (0.7 kg) in our } 2014 \text { 32-inch } \\
\text { TV model (Model: 32LB555B) compared to the } \\
\text { previous year's model (32LN5400) of the same size. }\end{array}$ & $\begin{array}{c}\text { LG } \\
(2014)\end{array}$ & $\begin{array}{l}\text { Innovative, } \\
\text { Reconfiguring }\end{array}$ \\
\hline 16 & $\begin{array}{c}\text { L6 } \\
\text { (Type II) }\end{array}$ & $\begin{array}{c}\text { LG's LED-backlit LCD TV achieved } 67 \text { percent } \\
\text { improved energy efficiency by using Smart Energy } \\
\text { Saving technology. }\end{array}$ & $\begin{array}{c}\text { LG } \\
(2014)\end{array}$ & $\begin{array}{l}\text { Innovative, } \\
\text { Reconfiguring }\end{array}$ \\
\hline 17 & $\begin{array}{c}\text { L6 } \\
\text { (Type II) }\end{array}$ & $\begin{array}{l}\text { Recognized by the EPA as ENERGY STAR Partner of } \\
\text { the Year for the past four years, LG is committed to } \\
\text { developing the most innovative and energy-efficient } \\
\text { products that provide consumers with superior } \\
\text { performance while achieving significant energy } \\
\text { savings and lessening the impact on the planet. }\end{array}$ & $\begin{array}{c}\text { LG } \\
(2015)\end{array}$ & Adaptive, Sensing \\
\hline 18 & $\begin{array}{c}\text { L6 } \\
\text { (Type II) }\end{array}$ & $\begin{array}{c}\text { Saving technology, LG's CURVED OLED TV reduces } \\
\text { energy usage as much as } 67 \text { percent compared to } \\
\text { conventional flat panel TVs. }\end{array}$ & $\begin{array}{c}\text { LG } \\
(2013)\end{array}$ & $\begin{array}{l}\text { Innovative, } \\
\text { Reconfiguring }\end{array}$ \\
\hline
\end{tabular}


Table A2. Cont.

\begin{tabular}{|c|c|c|c|c|}
\hline $\begin{array}{l}\text { Event } \\
\text { No. }\end{array}$ & $\begin{array}{c}\text { Evidence Category } \\
\text { (Ecopreneurship Type) }\end{array}$ & Description & Source & Dynamic Capabilities \\
\hline 19 & $\begin{array}{c}\text { L6 } \\
\text { (Type II) }\end{array}$ & $\begin{array}{l}\text { LG Electronics' Smart Energy Saving Plus technology } \\
\text { allows users to reduce power consumption with a } \\
\text { built-in power save option, which adjusts the } \\
\text { brightness and contrast depending upon the lighting } \\
\text { conditions in a room. This model is the only 55-inch } \\
\text { TV named as ENERGY STAR Most Efficient 2011. }\end{array}$ & $\begin{array}{c}\text { LG } \\
(2011)\end{array}$ & Innovative, Sensing \\
\hline 20 & $\begin{array}{c}\text { L6 } \\
\text { (Type II) }\end{array}$ & $\begin{array}{l}\text { The company is branding the new models under a } \\
\text { new "Nano" moniker, which it says refers to } \\
\text { improved local-dimming LED technology. } \\
\text { According to the release: "An extremely thin film } \\
\text { printed with a proprietary light dispersion pattern } \\
\text { combined with a full array of LEDs disperses light } \\
\text { more evenly across the screen, creating pictures that } \\
\text { are brighter and more uniform than conventional } \\
\text { edge-lit LED sets." }\end{array}$ & $\begin{array}{l}\text { CNET } \\
(2010)\end{array}$ & Innovative, Sensing \\
\hline 21 & $\begin{array}{c}\text { L6 } \\
\text { (Type II) }\end{array}$ & $\begin{array}{l}\text { According to the press release, "The Nano full LED } \\
\text { display employs a thin film incorporating a full array } \\
\text { of LEDs, giving it more uniform light distribution } \\
\text { and detailed local dimming from over two hundred } \\
\text { addressable sectors." }\end{array}$ & $\begin{array}{l}\text { CNET } \\
(2011)\end{array}$ & Innovative, Sensing \\
\hline 22 & $\begin{array}{c}\text { L7 } \\
\text { (Type III) }\end{array}$ & $\begin{array}{l}\text { LGE offers electronic waste take-back and disposal } \\
\text { service in } 85 \text { areas in } 51 \text { countries to meet the } \\
\text { requirements of Waste Electrical and Electronic } \\
\text { Equipment (WEEE) and the regulatory requirements } \\
\text { of respective countries (as of the end of 2019). For } \\
\text { new areas, we are introducing the services after } \\
\text { discussions with local governments and industrial } \\
\text { organizations, and analysis of regulations. } \\
\text { LGE has sioned an MOU with Geoje and Ulsan }\end{array}$ & $\begin{array}{c}\text { LG } \\
(2019)\end{array}$ & $\begin{array}{c}\text { Adaptive, } \\
\text { Reconfiguring }\end{array}$ \\
\hline 23 & $\begin{array}{c}\text { L7 } \\
\text { (Type III) }\end{array}$ & $\begin{array}{l}\text { Metropolitan City (Gyeongsang Province, Korea) } \\
\text { councils to carry out an electronic waste take-back } \\
\text { campaign in order to collect products regardless of } \\
\text { brands and makers. }\end{array}$ & $\begin{array}{c}\text { LG } \\
(2010)\end{array}$ & Adaptive, Seizing \\
\hline 24 & $\begin{array}{c}\text { L8 } \\
\text { (Type III) }\end{array}$ & $\begin{array}{l}\text { The company on Tuesday announced its Mosquito } \\
\text { Away line of TVs for the country. The South Korean } \\
\text { company says that its new TV comes equipped with } \\
\text { an ultrasonic device which uses sound waves to keep } \\
\text { mosquitoes at bay. } \\
\text { The company assures that the Mosquito Away TV } \\
\text { models don't emit any harmful radiation, nor do they } \\
\text { use chemicals. What's more, there is no need to refill } \\
\text { chemicals or worry about any other maintenance. }\end{array}$ & $\begin{array}{l}\text { CNET } \\
(2016)\end{array}$ & Innovative, Sensing \\
\hline
\end{tabular}


Table A2. Cont.

\begin{tabular}{|c|c|c|c|c|}
\hline $\begin{array}{l}\text { Event } \\
\text { No. }\end{array}$ & $\begin{array}{c}\text { Evidence Category } \\
\text { (Ecopreneurship Type) }\end{array}$ & Description & Source & Dynamic Capabilities \\
\hline 25 & $\begin{array}{c}\text { L9 } \\
\text { (Type I) }\end{array}$ & $\begin{array}{c}\text { Pretty much all OLED TVs also have user settings to } \\
\text { minimize the chance of uneven wear or burn-in. One } \\
\text { is called "Screen Shift" (on LGs) or "Pixel Shift" (on } \\
\text { Sonys), which moves the image slightly to remove } \\
\text { image retention. } \\
\text { LG also has a Daily Pixel Refresher, which it says } \\
\text { "automatically operates when users turn off the TV } \\
\text { after watching it for more than four hours in total. } \\
\text { For example, if a user watched TV for two hours } \\
\text { yesterday and three hours today (more than four } \\
\text { hours in total), when powered off, the Daily Pixel } \\
\text { Refresher will automatically run, deal with potential } \\
\text { image retention issues, and reset the operation time. } \\
\text { This process will occur when the TV is powered off } \\
\text { after every four hours of cumulative use, even if it's } \\
\text { in one sitting." }\end{array}$ & $\begin{array}{l}\text { CNET } \\
(2019)\end{array}$ & Innovative, Sensing \\
\hline 26 & $\begin{array}{c}\text { L9 } \\
\text { (Type I) }\end{array}$ & $\begin{array}{l}\text { OLED, on the other hand, is a new panel technology } \\
\text { that differs significantly from LED or LCD TVs. } \\
\text { OLED allows for the individual pixels to be turned } \\
\text { on and off rather than just dimmed, which makes for } \\
\text { significantly deeper blacks, aiding color contrast and } \\
\text { creating a brighter and more vivid image. }\end{array}$ & $\begin{array}{l}\text { CNET } \\
(2015)\end{array}$ & Innovative, Seizing \\
\hline
\end{tabular}

Table A3. Summary of Sony Case.

\begin{tabular}{|c|c|c|c|c|}
\hline $\begin{array}{c}\text { Event } \\
\text { No. }\end{array}$ & Evidence Category & Description & Source & Dynamic Capabilities \\
\hline 1 & $\begin{array}{c}\text { SN1 } \\
\text { (Type I) }\end{array}$ & $\begin{array}{l}\text { Color IQ }{ }^{\mathrm{TM}} \text { is an advanced light emitting } \\
\text { semiconductor incorporating quantum dot } \\
\text { technology, developed by QD Vision, Inc. This } \\
\text { component contains very small semiconductor } \\
\text { particles which are fixed within hardened resin } \\
\text { and then sealed in glass. When lights of specific } \\
\text { wavelengths hit this tube, they are changed into } \\
\text { high purity blues, greens, and reds that are } \\
\text { mixed to produce white light. This TV is } \\
\text { therefore able to achieve a color gamut that far } \\
\text { exceeds conventional LCD television sets using } \\
\text { edge-lit single color LED backlight systems. } \\
\text { The } 8 \mathrm{~K} \text { versions bring back Sonv's Backlight }\end{array}$ & $\begin{array}{l}\text { Sony } \\
(2013)\end{array}$ & Absorptive, Sensing \\
\hline 2 & $\begin{array}{c}\text { SN2 } \\
\text { (Type I) }\end{array}$ & $\begin{array}{l}\text { Master Drive technology, which utilizes } \\
\text { "ultra-dense LED modules that are } \\
\text { independently controlled" and can } \\
\text { "intelligently boost the brightness in the areas } \\
\text { where it needs to be boosted." }\end{array}$ & $\begin{array}{l}\text { CNET } \\
(2019)\end{array}$ & Innovative, Seizing \\
\hline 3 & $\begin{array}{c}\text { SN2 } \\
\text { (Type I) }\end{array}$ & $\begin{array}{l}\text { The Sony KDL-EX700 is the second edge-lit } \\
\text { LED based LCD from Sony this year. The } \\
\text { EX700 consumes as little power as any TV } \\
\text { we've tested, although we expect other LED } \\
\text { models to follow suit this year. }\end{array}$ & $\begin{array}{l}\text { CNET } \\
(2010)\end{array}$ & Adaptive, Seizing \\
\hline
\end{tabular}


Table A3. Cont.

\begin{tabular}{|c|c|c|c|c|}
\hline $\begin{array}{c}\text { Event } \\
\text { No. }\end{array}$ & Evidence Category & Description & Source & Dynamic Capabilities \\
\hline 4 & $\begin{array}{c}\text { SN2 } \\
\text { (Type I) }\end{array}$ & $\begin{array}{l}\text { Sony XBR-HX909 was the company's first } \\
\text { television to include our favorite kind of LED } \\
\text { backlight-full array with local } \\
\text { dimming—since the excellent KDL-XBR8 from } \\
\text { 2008. } \\
\text { For 2011, Sony's flagship television, the } \\
\text { XBR-HX929, offers a similar LED backlight and } \\
\text { a few improvements. According to the release: } \\
\text { "Sony's Intelligent Peak LED Backlight uses full } \\
\text { array local dimming for deeper blacks, while } \\
\text { also boosting brightness in lighter scenes } \\
\text { creating incredible on-screen contrast." }\end{array}$ & $\begin{array}{l}\text { CNET } \\
(2011)\end{array}$ & Adaptive, Seizing \\
\hline 5 & $\begin{array}{c}\text { SN2 } \\
\text { (Type I) }\end{array}$ & $\begin{array}{l}\text { The KDL-65S990A is the world's first } \\
\text { LED-based LCD TV with a curved, concave } \\
\text { screen. The curved S990A has the same edge-lit } \\
\text { LED backlight with local dimming and the } \\
\text { Triluminos technology we liked so much on the } \\
\text { fat W900A. Of course, those LEDs are now } \\
\text { arranged in a gentle arc along the top and } \\
\text { bottom edge of the TV, and there's no telling } \\
\text { how that curve affects picture quality, } \\
\text { particularly screen uniformity. }\end{array}$ & $\begin{array}{l}\text { CNET } \\
(2013)\end{array}$ & Adaptive, Sensing \\
\hline 6 & $\begin{array}{c}\text { SN2 } \\
\text { (Type I) }\end{array}$ & $\begin{array}{l}\text { Sony's array of LED LCD TVs at CES } 2014 \text { is } \\
\text { topped by the XBR-X950B series, its first } 4 \text { K set } \\
\text { to include local dimming in a full-array LED } \\
\text { backlight. } \\
\text { We're fans of the effect of local dimming, an } \\
\text { LED LCD backlight technology that dims } \\
\text { particular parts of the screen to improve } \\
\text { contrast, the single most important picture } \\
\text { quality factor. The X950B series promises some } \\
\text { of the best dimming technology around. }\end{array}$ & $\begin{array}{l}\text { CNET } \\
(2014)\end{array}$ & Adaptive, Sensing \\
\hline 7 & $\begin{array}{c}\text { SN2 } \\
\text { (Type I) }\end{array}$ & $\begin{array}{l}\text { The more-expensive X930E uses edge lighting } \\
\text { while the X900E uses full-array. Despite the fact } \\
\text { that full-array usually performs better in our } \\
\text { tests, Sony says the edge-lit X930E is actually } \\
\text { the superior performer with better contrast } \\
\text { (light output and black levels), thanks to an } \\
\text { improved version of the Slim Backlight Drive } \\
\text { system we liked so much last year. }\end{array}$ & $\begin{array}{l}\text { CNET } \\
(2017)\end{array}$ & Adaptive, Sensing \\
\hline 8 & $\begin{array}{c}\text { SN2 } \\
\text { (Type I) }\end{array}$ & $\begin{array}{c}\text { The best picture-enhancing extra on the X900F } \\
\text { is full-array local dimming (FALD). It improves } \\
\text { black levels and contrast by illuminating } \\
\text { different areas of the screen separately as } \\
\text { needed. }\end{array}$ & $\begin{array}{l}\text { CNET } \\
(2018)\end{array}$ & Adaptive, Sensing \\
\hline 9 & $\begin{array}{c}\text { SN2 } \\
\text { (Type I) }\end{array}$ & $\begin{array}{c}\text { The best picture-enhancing extra on the X950G } \\
\text { is full-array local dimming (FALD). It improves } \\
\text { black levels and contrast by illuminating } \\
\text { different areas of the screen separately as } \\
\text { needed. }\end{array}$ & $\begin{array}{l}\text { CNET } \\
(2019)\end{array}$ & Adaptive, Sensing \\
\hline
\end{tabular}


Table A3. Cont.

\begin{tabular}{|c|c|c|c|c|}
\hline $\begin{array}{c}\text { Event } \\
\text { No. }\end{array}$ & Evidence Category & Description & Source & Dynamic Capabilities \\
\hline 10 & $\begin{array}{c}\text { SN3 } \\
\text { (Type I) }\end{array}$ & $\begin{array}{l}\text { The electronics and entertainment giant kicked } \\
\text { off its CES press conference this evening by } \\
\text { unveiling a prototype "Crystal LED display" } \\
\text { that uses miniature light-emitting diodes in } \\
\text { place of pixels. The technology, which uses } 6 \\
\text { million LEDs mounted on the front of the } \\
\text { display, is superior to LCD and plasma and } \\
\text { promises "super contrast and super-wide color } \\
\text { gamut," Sony CEO Howard Stringer told those } \\
\text { assembled. }\end{array}$ & $\begin{array}{l}\text { CNET } \\
(2012)\end{array}$ & Innovative, Sensing \\
\hline 11 & $\begin{array}{c}\text { SN4 } \\
\text { (Type I) }\end{array}$ & $\begin{array}{c}\text { The company entered the OLED fray with the } \\
\text { new A1E series. They come in 55-, 65-, and } \\
\text { 77-inch sizes, run on Android, and work with } \\
\text { Google Home. }\end{array}$ & $\begin{array}{l}\text { CNET } \\
(2017)\end{array}$ & Adaptive, Seizing \\
\hline 12 & $\begin{array}{c}\text { SN4 } \\
\text { (Type I) }\end{array}$ & $\begin{array}{l}\text { The A9F OLED comes with technologies } \\
\text { including Pixel Contrast Booster, which is } \\
\text { designed to boost colors at high brightness } \\
\text { levels. The TVs incorporate Sony's } \\
\text { next-generation Picture Processor X1 Ultimate, } \\
\text { which it says can "intelligently detect and } \\
\text { analyze each object in the picture through } \\
\text { Sony's new Object-based Super Resolution for } \\
\text { exceptional accuracy and detail." }\end{array}$ & $\begin{array}{l}\text { CNET } \\
(2018)\end{array}$ & Innovative, Sensing \\
\hline 13 & $\begin{array}{c}\text { SN5 } \\
\text { (Type II) }\end{array}$ & $\begin{array}{l}\text { The price disparity of } \$ 400 \text { between the two } \\
\text { series' } 46 \text {-inch members gets you improved } \\
\text { styling, Wi-Fi networking, and a couple of other } \\
\text { minor niceties on the NX800, but for some } \\
\text { reason loses you the innovative "presence } \\
\text { sensor." That feature turns the EX700's picture } \\
\text { off automatically when you leave the room, and } \\
\text { can really save power use if you're prone to } \\
\text { leaving the TV on. }\end{array}$ & $\begin{array}{l}\text { CNET } \\
(2010)\end{array}$ & Adaptive, Seizing \\
\hline 14 & $\begin{array}{c}\text { SN5 } \\
\text { (Type II) }\end{array}$ & $\begin{array}{l}\text { You can now access the Google Assistant from } \\
\text { select Sony TVs. They'll let you search for TV } \\
\text { shows and movies and control smart home } \\
\text { devices, just as you'd use a Google Home } \\
\text { speaker. There are a couple of catches, however. } \\
\text { Google Assistant is only coming to Sony TVs } \\
\text { with } 4 \text { K displays and built-in Android TV } \\
\text { software. } \\
\text { In a press release, Mike Fasulo, President and } \\
\text { COO of Sony Electronics, said: "Sony's goal is } \\
\text { to provide our customers the Smart Home } \\
\text { functionality they desire in the manner they } \\
\text { choose. With the Google Assistant, Sony TV } \\
\text { owners get all the answers and tasks they need } \\
\text { to be done, just by using their voice." }\end{array}$ & $\begin{array}{l}\text { CNET } \\
(2017)\end{array}$ & $\begin{array}{l}\text { Absorptive, } \\
\text { Reconfiguring }\end{array}$ \\
\hline
\end{tabular}


Table A3. Cont.

\begin{tabular}{|c|c|c|c|c|}
\hline $\begin{array}{c}\text { Event } \\
\text { No. }\end{array}$ & Evidence Category & Description & Source & Dynamic Capabilities \\
\hline 15 & $\begin{array}{c}\text { SN5 } \\
\text { (Type II) }\end{array}$ & $\begin{array}{l}\text { Sony's eco mode works really well, and we're } \\
\text { very impressed by it. The TV's "presence } \\
\text { sensor" will know if you leave the room for any } \\
\text { length of time, and the set will then turn off the } \\
\text { picture, leaving the sound on, which is handy if } \\
\text { you're still listening to a program from another } \\
\text { room. } \\
\text { After longer periods of absence, the set will } \\
\text { switch itself off completely. } \\
\text { That's good news if you're one of those people } \\
\text { who leaves the room to get a drink and then } \\
\text { gets distracted by something in the kitchen. }\end{array}$ & $\begin{array}{l}\text { CNET } \\
(2010)\end{array}$ & Adaptive, Seizing \\
\hline 16 & $\begin{array}{c}\text { SN6 } \\
\text { (Type III) }\end{array}$ & $\begin{array}{l}\text { Sony provides its consumers, authorized repair } \\
\text { workshops, and recycling companies with } \\
\text { information relating to the "Color IQ }{ }^{\mathrm{TM}} \text { " } \\
\text { component to enable proper collection, } \\
\text { handling, recycling, and disposal of the } \\
\text { component upon repair or disposal of the } \\
\text { television, in accordance with local } \\
\text { environmental laws and regulations. }\end{array}$ & $\begin{array}{c}\text { Sony } \\
\text { (2013) }\end{array}$ & Adaptive, Sensing \\
\hline 17 & $\begin{array}{c}\text { SN7 } \\
\text { (Type I) }\end{array}$ & $\begin{array}{l}\text { The company is calling its new XBR-X900C the } \\
\text { thinnest LCD TV yet. Parts of the TV's cabinet, } \\
\text { namely the top half of the set, measure just } 0.2 \\
\text { inch thick. That's just } 7.1 \mathrm{~mm} \text {, thinner than an } \\
\text { iPhone } 6 \text {, for example. The fact that the bottom } \\
\text { half is a bit thicker to accommodate internal } \\
\text { components and inputs spoils the effect only a } \\
\text { little. }\end{array}$ & $\begin{array}{l}\text { CNET } \\
(2015)\end{array}$ & Innovative, Seizing \\
\hline
\end{tabular}

Table A4. Summary of Hisense Case.

\begin{tabular}{|c|c|c|c|c|}
\hline $\begin{array}{l}\text { Event } \\
\text { No. }\end{array}$ & Evidence Category & Description & Source & Dynamic Capabilities \\
\hline 1 & $\begin{array}{c}\text { H1 } \\
\text { (Type I) }\end{array}$ & $\begin{array}{l}\text { ULED XD's panel design layers a 1080p module } \\
\text { displaying a grayscale image between a full } \\
\text { array LED backlight and a } 4 \mathrm{~K} \text { module } \\
\text { displaying a full color image. Hisense claims } \\
\text { that they improved dynamic range, brightness } \\
\text { (2900 nits), and black levels. }\end{array}$ & $\begin{array}{l}\text { CNET } \\
(2019)\end{array}$ & $\begin{array}{l}\text { Innovative, } \\
\text { Reconfiguring }\end{array}$ \\
\hline 2 & $\begin{array}{c}\text { H1 } \\
\text { (Type I) }\end{array}$ & $\begin{array}{c}\text { Hisense exhibited a 75-inch 8K ULED XD TV } \\
\text { based on the dual layer LCD technology at CES } \\
2019 .\end{array}$ & $\begin{array}{l}\text { FlatpanelsHD } \\
\qquad(2019)\end{array}$ & $\begin{array}{l}\text { Innovative, } \\
\text { Reconfiguring }\end{array}$ \\
\hline 3 & $\begin{array}{c}\text { H1 } \\
\text { (Type I) }\end{array}$ & $\begin{array}{l}\text { Hisense exhibited a prototype under the name } \\
\text { "ULED XD". "Dual-cell ULED XD panel creates } \\
\text { significant upgrades in local dimming, colors } \\
\text { and dynamic range" the company said at CES. }\end{array}$ & $\begin{array}{l}\text { CNET } \\
(2019)\end{array}$ & $\begin{array}{c}\text { Innovative, } \\
\text { Reconfiguring }\end{array}$ \\
\hline 4 & $\begin{array}{c}\text { H1 } \\
\text { (Type I) }\end{array}$ & $\begin{array}{c}\text { Hisense showcased a dual LCD panel called } \\
\text { "ULED XD" at CES 2019. The idea is to stack } \\
\text { two LCD panels on top of a full array LED } \\
\text { backlight. The first LCD is a 1080p } \\
\text { monochrome panel designed to modulate } \\
\text { luminance, while the other is a regular 4K LCD } \\
\text { panel. }\end{array}$ & $\begin{array}{l}\text { FlatpanelsHD } \\
\text { (2019) }\end{array}$ & $\begin{array}{c}\text { Innovative, } \\
\text { Reconfiguring }\end{array}$ \\
\hline
\end{tabular}


Table A4. Cont.

\begin{tabular}{|c|c|c|c|c|}
\hline $\begin{array}{c}\text { Event } \\
\text { No. }\end{array}$ & Evidence Category & Description & Source & Dynamic Capabilities \\
\hline 5 & $\begin{array}{c}\mathrm{H} 2 \\
\text { (Type II) }\end{array}$ & $\begin{array}{l}\text { Hisense pushes its new Series } 9 \mathrm{TV} \text {, which has } \\
2200 \text { nits of brightness, as the brightest panel } \\
\text { it's ever manufactured. Hisense calls this } \\
\text { feature "HDR Supreme". Combining quantum } \\
\text { dot technology and HDR support means the } \\
\text { panel performed well when tested on colorful } \\
\text { content in HDR. }\end{array}$ & $\begin{array}{l}\text { CNET } \\
(2017)\end{array}$ & Innovative, Sensing \\
\hline 6 & $\begin{array}{c}\text { H3 } \\
\text { (Type II) }\end{array}$ & $\begin{array}{l}\text { Hisense showed off ULED, which is based on } \\
\text { LCD with support for HDR and a wider color } \\
\text { gamut. Its ULED TV employs quantum dot } \\
\text { technology in order to position ULED as a } \\
\text { competitor to OLED. }\end{array}$ & $\begin{array}{c}\text { FlatpanelsHD } \\
\text { (2015) }\end{array}$ & Innovative, Sensing \\
\hline 7 & $\begin{array}{c}\text { H3 } \\
\text { (Type II) }\end{array}$ & $\begin{array}{l}\text { Hisense announced the third generation of its } \\
\text { ULED TVs, which use LCD panels with } \\
\text { quantum dot technology that enables them to } \\
\text { reproduce HDR and a wider color gamut. }\end{array}$ & $\begin{array}{l}\text { FlatpanelsHD } \\
\text { (2016) }\end{array}$ & Innovative, Sensing \\
\hline 8 & $\begin{array}{c}\text { H3 } \\
\text { (Type II) }\end{array}$ & $\begin{array}{l}\text { M7000 is the second generation of Hisense's } \\
\text { ULED TVs with support of HDR and wide } \\
\text { color gamut. Hisense has equipped the TVs } \\
\text { with some form of local dimming, built-in WiFi, } \\
\text { and apps such as Netflix and YouTube. }\end{array}$ & $\begin{array}{l}\text { FlatpanelsHD } \\
\text { (2016) }\end{array}$ & Innovative, Sensing \\
\hline 9 & $\begin{array}{c}\text { H3 } \\
\text { (Type II) }\end{array}$ & $\begin{array}{l}\text { Some H series models will be sold under ULED } \\
\text { naming. H10D series feature full array local } \\
\text { dimming and is Ultra HD Premium certified. }\end{array}$ & $\begin{array}{l}\text { FlatpanelsHD } \\
\text { (2017) }\end{array}$ & Innovative, Sensing \\
\hline 10 & $\begin{array}{c}\text { H3 } \\
\text { (Type II) }\end{array}$ & $\begin{array}{l}\text { The } 2018 \text { flagship TV from Hisense, the H10E } \\
\text { (U9 in Europe) model, can hit } 2500 \text { nits peak } \\
\text { brightness because it uses a full array local } \\
\text { dimming with more than } 1000 \text { dimming zones. }\end{array}$ & $\begin{array}{l}\text { FlatpanelsHD } \\
\qquad(2018)\end{array}$ & Innovative, Sensing \\
\hline
\end{tabular}

Table A5. Summary of TCL Case.

\begin{tabular}{|c|c|c|c|c|}
\hline Event No. & Evidence Category & Description & Sources & Dynamic Capabilities \\
\hline 1 & $\begin{array}{c}\text { T1 } \\
\text { (Type I) }\end{array}$ & $\begin{array}{l}\text { TCL unveiled its } 8 \text { Series of } 4 \text { K LCD } \\
\text { TVs with more than } 25,000 \text { individual } \\
\text { mini-LED backlights ( } 75 \text {-inch). Using } \\
\text { mini-LED backlights, } 8 \text { Series have } \\
\text { increased brightness, increased local } \\
\text { dimming zones, and enhanced } \\
\text { reproduction of color. }\end{array}$ & $\begin{array}{l}\text { FlatpanelsHD } \\
\text { (2019) }\end{array}$ & Innovative, Sensing \\
\hline 2 & $\begin{array}{c}\text { T1 } \\
\text { (Type I) }\end{array}$ & $\begin{array}{l}\text { Mini-LED technology promises better } \\
\text { contrast and pop thanks to more } \\
\text { light-emitting diodes behind the } \\
\text { screen. }\end{array}$ & $\begin{array}{l}\text { CNET } \\
(2019)\end{array}$ & Innovative, Sensing \\
\hline 3 & $\begin{array}{c}\text { T1 } \\
\text { (Type I) }\end{array}$ & $\begin{array}{l}\text { TCL's Mini-LED based prototype } \\
\text { display increases peak brightness, } \\
\text { improves luminance control, and is } \\
\text { slimmer than conventional LED. }\end{array}$ & $\begin{array}{l}\text { FlatpanelsHD } \\
\qquad(2018)\end{array}$ & Innovative, Sensing \\
\hline
\end{tabular}


Table A5. Cont.

\begin{tabular}{|c|c|c|c|c|}
\hline Event No. & Evidence Category & Description & Sources & Dynamic Capabilities \\
\hline 4 & $\begin{array}{c}\text { T1 } \\
\text { (Type I) }\end{array}$ & $\begin{array}{l}\text { The European version of TCL's } 8 \\
\text { Series (X10) is the first LCD TV using } \\
\text { a mini-LED backlight. TCL's } \\
\text { mini-LED engine brings contrast, } \\
\text { details, and enhanced picture quality } \\
\text { to a whole new level. }\end{array}$ & $\begin{array}{l}\text { FlatpanelsHD } \\
\quad(2019)\end{array}$ & Innovative, Sensing \\
\hline 5 & $\begin{array}{c}\text { T1 } \\
\text { (Type I) }\end{array}$ & $\begin{array}{l}\text { The } 8 \text { Series is equipped with a full } \\
\text { array of local dimming based on } \\
\text { TCL's industry-first mini-LED } \\
\text { technology. Due to its small size, } \\
\text { mini-LEDs can be grouped into more } \\
\text { local dimming zones. }\end{array}$ & $\begin{array}{l}\text { CNET } \\
(2019)\end{array}$ & Innovative, Sensing \\
\hline 6 & $\begin{array}{c}\text { T2 } \\
\text { (Type I) }\end{array}$ & $\begin{array}{l}\text { TCL has started pushing QLED } \\
\text { together with Samsung and Hisense. } \\
\text { TCL QLED enables X2 to display } \\
\text { richer colors with contrast optimized } \\
\text { with Ultra Micro Dimming. }\end{array}$ & $\begin{array}{l}\text { FlatpanelsHD } \\
\quad(2017)\end{array}$ & Innovative, Sensing \\
\hline 7 & $\begin{array}{c}\text { T2 } \\
\text { (Type I) }\end{array}$ & $\begin{array}{l}\text { TCL announced that it is developing a } \\
\text { hybrid QLED display, referred to as } \\
\text { H-QLED at the } 2019 \text { Korea OLED } \\
\text { conference. H-QLED uses a blue } \\
\text { OLED emitter coupled with red and } \\
\text { green QLED emitters, produced with } \\
\text { inkjet printing. }\end{array}$ & $\begin{array}{l}\text { FlatpanelsHD } \\
\quad(2019)\end{array}$ & Innovative, Seizing \\
\hline 8 & $\begin{array}{c}\text { T2 } \\
\text { (Type I) }\end{array}$ & $\begin{array}{l}\text { TCL says X1 is the slimmest HDR local } \\
\text { dimming LCD TV. X } 1 \text { can reproduce } \\
93 \% \text { of the DCI-P3 color gamut by } \\
\text { utilizing cadmium-free quantum dots. }\end{array}$ & $\begin{array}{l}\text { FlatpanelsHD } \\
\quad(2016)\end{array}$ & Innovative, Sensing \\
\hline 9 & $\begin{array}{c}\text { T2 } \\
\text { (Type I) }\end{array}$ & $\begin{array}{l}\text { TCL's } 6 \text { Series has improved color for } \\
2019 \text { thanks to quantum dots. }\end{array}$ & $\begin{array}{l}\text { CNET } \\
(2019)\end{array}$ & Innovative, Sensing \\
\hline 10 & $\begin{array}{c}\text { T3 } \\
\text { (Type I) }\end{array}$ & $\begin{array}{l}\text { The TV is } 17.4 \mathrm{~mm} \text { in depth, but TCL } \\
\text { still managed to fit a full-array local } \\
\text { dimming system into the cabinet. TCL } \\
\text { says that } \mathrm{X} 1 \text { is the "slimmest HDR } \\
\text { local dimming LCD TV". }\end{array}$ & $\begin{array}{l}\text { FlatPanelsHS } \\
\quad(2016)\end{array}$ & Innovative, Sensing \\
\hline 11 & $\begin{array}{c}\text { T3 } \\
\text { (Type I) }\end{array}$ & $\begin{array}{l}\text { At CES in Las Vegas, TCL unveiled its } \\
\text { "Xclusive" TV. The 65-inch LCD TV } \\
\text { uses quantum dot LEDs and a } \\
\text { full-array local dimming ( } 288 \text { zones) } \\
\text { system to reproduce pictures in } 4 \mathrm{~K} \\
\text { resolution, HDR, and a wide color } \\
\text { gamut. }\end{array}$ & $\begin{array}{l}\text { FlatpanelsHD } \\
\quad(2016)\end{array}$ & Innovative, Sensing \\
\hline 12 & $\begin{array}{c}\text { T3 } \\
\text { (Type I) }\end{array}$ & $\begin{array}{l}\text { Full-array local dimming is the best } \\
\text { way to improve picture quality on } \\
\text { LCD TVs. It allows the backlight-the } \\
\text { part behind the LCD screen that } \\
\text { provides illumination-to dim and } \\
\text { illuminate different areas } \\
\text { simultaneously. }\end{array}$ & $\begin{array}{l}\text { CNET } \\
(2019)\end{array}$ & Innovative, Sensing \\
\hline 13 & $\begin{array}{c}\text { T4 } \\
\text { (Type III) }\end{array}$ & $\begin{array}{l}\text { Our ongoing support of the collection } \\
\text { and recycling of televisions and other } \\
\text { electronic products across the country } \\
\text { helps improve communities and } \\
\text { neighborhoods by keeping old } \\
\text { equipment out of landfills. }\end{array}$ & $\begin{array}{l}\text { TCL } \\
\text { (n.d.) }\end{array}$ & Adaptive, Sensing \\
\hline
\end{tabular}




\section{References}

1. Niero, M.; Rivera, X.C.S. The role of life cycle sustainability assessment in the implementation of circular economy principles in organizations. In Proceedings of the 25th CIRP Life Cycle Engineering (LCE) Conference, Copenhagen, Denmark, 30 April-2 May 2018.

2. Hankammer, S.; Brenk, S.; Fabry, H.; Nordemann, A.; Piller, F.T. Towards circular business models: Identifying consumer needs based on the jobs-to-be-done theory. J. Clean. Prod. 2019, 231, 341-358. [CrossRef]

3. Geissdoerfer, M.; Savaget, P.; Bocken, N.M.P.; Hultink, E.J. The circular economy-A new sustainability paradigm? J. Clean. Prod. 2017, 143, 757-768. [CrossRef]

4. Hallstedt, S.I.; Thompson, A.W.; Lindahl, P. Key elements for implementing a strategic sustainability perspective in the product innovation process. J. Clean. Prod. 2013, 51, 277-288. [CrossRef]

5. Pigosso, D.C.A.; Ferraz, M.; Teixeira, C.E.; Rozenfeld, H. The Deployment of Product-Related Environmental Legislation into Product Requirements. Sustainability 2016, 8, 332. [CrossRef]

6. Avila-Gutierrez, M.J.; Martin-Gomez, A.; Aguayo-Gonzalez, F.; Cordoba-Roldan, A. Standardization framework for sustainability from circular economy 4.0. Sustainability 2019, 11, 6490. [CrossRef]

7. Umeda, Y.; Takata, S.; Kimura, F.; Tomiyama, T.; Sutherland, J.W.; Kara, S.; Herrmann, C.; Duflou, J.R. Toward integrated product and process life cycle planning-An environmental perspective. CIRP Ann. 2012, 61, 681-702. [CrossRef]

8. Andabaka, A.; Sertić, M.B.; Harc, M. Eco-innovation and Economic Growth in the European Union. Zagreb Int. Rev. Econ. Bus. 2019, 22, 43-54. [CrossRef]

9. Rodríguez-García, M.; Guijarro-García, M.; Carrilero-Castillo, A. An overview of ecopreneurship, eco-innovation, and the ecological sector. Sustainability 2019, 11, 2909. [CrossRef]

10. Kiefer, C.P.; Carrillo-Hermosilla, J.; Del Río, P. Building a taxonomy of eco-innovation types in firms. A quantitative perspective. Resour. Conserv. Recycl. 2019, 145, 339-348. [CrossRef]

11. Teece, D.J.; Pisano, G.; Shuen, A. Dynamic capabilities and strategic management. Strat. Manag. J. 1997, 18, 509-533. [CrossRef]

12. Abdelkafi, N.; Hansen, E.G. Ecopreneurs' creation of user business models for green tech: An exploratory study in e-mobility. Int. J. Entrep. Ventur. 2018, 10, 32-55. [CrossRef]

13. Flynn, A.; Hacking, N. Setting standards for a circular economy: A challenge too far for neoliberal environmental governance? J. Clean. Prod. 2019, 212, 1256-1267. [CrossRef]

14. Hughes, R. The EU circular economy package-Life cycle thinking to life cycle law? In Proceedings of the 24th CIRP Conference on Life Cycle Engineering, Kamakura, Japan, 8-10 March 2017.

15. Tecchio, P.; McAlister, C.; Mathieux, F.; Ardente, F. In search of standards to support circularity in product policies: A systematic approach. J. Clean. Prod. 2017, 168, 1533-1546. [CrossRef]

16. Ghisellini, P.; Cialani, C.; Ulgiati, S. A review on circular economy: The expected transition to a balanced interplay of environmental and economic systems. J. Clean. Prod. 2016, 114, 11-32. [CrossRef]

17. Tamayo-Orbegozo, U.; Vicente-Molina, M.-A.; Villarreal-Larrinaga, O. Eco-innovation strategic model. A multiple-case study from a highly eco-innovative European region. J. Clean. Prod. 2017, 142, 1347-1367. [CrossRef]

18. Gaziulusoy, A.I. A critical review of approaches available for design and innovation teams through the perspective of sustainability science and system innovation theories. J. Clean. Prod. 2015, 107, 366-377. [CrossRef]

19. Doran, J.; Ryan, G. Regulation and firm perception, eco-innovation and firm performance. Eur. J. Innov. Manag. 2012, 15, 421-441. [CrossRef]

20. Cai, W.; Li, G. The drivers of eco-innovation and its impact on performance: Evidence from China. J. Clean. Prod. 2018, 176, 110-118. [CrossRef]

21. Rossi, M.; Papetti, A.; Marconi, M.; Germani, M. A multi-criteria index to support ecodesign implementation in manufacturing products: Benefits and limits in real case studies. Int. J. Sustain. Eng. 2019, 12, 376-389. [CrossRef]

22. Lehtoranta, S.; Nissinen, A.; Mattila, T.; Melanen, M. Industrial symbiosis and the policy instruments of sustainable consumption and production. J. Clean. Prod. 2011, 19, 1865-1875. [CrossRef]

23. Singh, P.K.; Sarkar, P. A framework based on fuzzy AHP-TOPSIS for prioritizing solutions to overcome the barriers in the implementation of ecodesign practices in SMEs. Int. J. Sustain. Dev. World Ecol. 2019, 26, 506-521. [CrossRef]

24. Dalhammar, C. Industry attitudes towards ecodesign standards for improved resource efficiency. J. Clean. Prod. 2016, 123, 155-166. [CrossRef]

25. Park, W.Y.; Phadke, A.A. Adoption of energy-efficient televisions for expanded off-grid electricity service. Dev. Eng. 2017, 2. [CrossRef]

26. Paparoidamis, N.G.; Tran, T.T.H.; Leonidou, L.C.; Zeriti, A. Being Innovative While Being Green: An Experimental Inquiry into How Consumers Respond to Eco-Innovative Product Designs. J. Prod. Innov. Manag. 2019, 36. [CrossRef]

27. Pearce, D.W.; Turner, R.K. Economics of Natural Resources and the Environment; Johns Hopkins University Press: Baltimore, MD, USA, 1989.

28. Polverini, D.; Miretti, U. An approach for the techno-economic assessment of circular economy requirements under the Ecodesign Directive. Resour. Conserv. Recycl. 2019, 150, 104425. [CrossRef]

29. Turunen, T. Deconstructing the Bottlenecks Caused by Waste Legislation: End-of-Waste Regulation. J. Eur. Environ. Plan. Law 2017, 14, 186-207. [CrossRef] 
30. Bundgaard, A.M.; Mosgaard, M.A.; Remmen, A. From energy efficiency towards resource efficiency within the Ecodesign Directive. J. Clean. Prod. 2017, 144, 358-374. [CrossRef]

31. McDonough, W.; Braungart, M. Cradle to Cradle: Remaking the Way We Make Things, 1st ed.; North Point Press: New York, NY, USA, 2010; pp. 53-54.

32. European Commission. Available online: https:/ / ec.europa.eu/environment/ecoap/indicators/business-operations_en (accessed on 29 March 2021).

33. Cordova-Pizarro, D.; Aguilar-Barajas, I.; Romero, D.; Rodriguez, C.A. Circular economy in the electronic products sector: Material flow analysis and economic impact of cellphone e-waste in Mexico. Sustainability 2019, 11, 1361. [CrossRef]

34. ECEEE. Available online: https://www.eceee.org/ecodesign/products/televisions/ (accessed on 29 March 2021).

35. International Resource Panel (IRP). Resource Efficiency and Climate Change: Material Efficiency Strategies for a Low-Carbon Future. Available online: https://www.resourcepanel.org/reports/resource-efficiency-and-climate-change (accessed on 29 March 2021).

36. UNEP; IRP. Sustainable Trade in Resources: Global Material Flows, Circularity and Trade. Available online: https://www. resourcepanel.org/reports/sustainable-trade-resources (accessed on 29 March 2021).

37. Kiefer, C.P.; González, P.D.R.; Carrillo-hermosilla, J. Drivers and barriers of eco-innovation types for sustainable transitions: A quantitative perspective. Bus. Strat. Environ. 2019, 28, 155-172. [CrossRef]

38. Munodawafa, R.T.; Johl, S.K. A systematic review of eco-innovation and performance from the resource-based and stakeholder perspectives. Sustainability 2019, 11, 6067. [CrossRef]

39. Blind, K.; Petersen, S.S.; Riillo, C.A.F. The impact of standards and regulation on innovation in uncertain markets. Res. Policy 2017, 46, 249-264. [CrossRef]

40. Spulber, D.F. Regulations and Markets, 1st ed.; MIT Press: Cambridge, MA, USA, 1989.

41. Blind, K. The influence of regulations on innovation: A quantitative assessment for OECD countries. Res. Policy 2012, 41, 391-400. [CrossRef]

42. IEC. IEC 60050-901 International Electrotechnical Vocabulary_Part 901: Standardization; IEC: Geneva, Switzerland, 2013.

43. Stavropoulos, S.; Wall, R.; Xu, Y. Environmental regulations and industrial competitiveness: Evidence from China. Appl. Econ. 2018, 50, 1378-1394. [CrossRef]

44. WTO. Decisions and Recommendations Adopted by the WTO Committee on Technical Barriers to Trade Since 1 January 1995; WTO: Geneva, Switzerland, 2019.

45. Landi, D.; Capitanelli, A.; Germani, M. Ecodesign and Energy Labelling: The Role of Virtual Prototyping. In Proceedings of the 24th CIRP Conference on Life Cycle Engineering, Kamakura, Japan, 8-10 March 2017.

46. Houe, R.; Grabot, B. Assessing the compliance of a product with an eco-label: From standards to constraints. Int. J. Prod. Econ. 2009, 121, 21-38. [CrossRef]

47. IEC. IEC 60050-902 International Electrotechnical Vocabulary_Part 902: Conformity Assessment; IEC: Geneva, Switzerland, 2013.

48. Directive 2009/125/EC of the European Parliament and of the Council of 21 October 2009 Establishing a Framework for the Setting of Ecodesign Requirements for Energy-Related Products. Available online: https:/ / eur-lex.europa.eu/legal-content/EN/ TXT/?uri=CELEX:32009L0125 (accessed on 25 February 2021).

49. Cole, C.; Gnanapragasam, A.; Cooper, T.; Singh, J. An assessment of achievements of the WEEE Directive in promoting movement up the waste hierarchy: Experiences in the UK. Waste Manag. 2019, 87, 417-427. [CrossRef]

50. Zacho, K.O.; Bundgaard, A.M.; Mosgaard, M.A. Constraints and opportunities for integrating preparation for reuse in the Danish WEEE management system. Resour. Conserv. Recycl. 2018, 138, 13-23. [CrossRef]

51. Rennings, K.; Rammer, C. The impact of regulation-driven environmental innovation on innovation success and firm performance. Ind. Innov. 2011, 18, 255-283. [CrossRef]

52. Pinheiro, M.A.P.; Jugend, D.; Filho, L.C.D.; Armellini, F. Framework proposal for ecodesign integration on product portfolio management. J. Clean. Prod. 2018, 185, 176-186. [CrossRef]

53. Audretsch, D.B.; Bozeman, B.; Combs, K.L.; Feldman, M.; Link, A.N.; Siegel, D.S.; Stephan, P.; Tassey, G.; Wessner, C. The economics of science and technology. J. Technol. Transf. 2002, 27, 155-203. [CrossRef]

54. Gaddefors, J.; Anderson, A.R. Entrepreneursheep and context: When entrepreneurship is greater than entrepreneurs. Int. J. Entrep. Behav. Res. 2017, 23, 267-278. [CrossRef]

55. Alvarez, S.A.; Busenitz, L.W. The entrepreneurship of resource-based theory. J. Manag. 2001, 27, 755-775. [CrossRef]

56. Gast, J.; Gundolf, K.; Cesinger, B. Doing business in a green way: A systematic review of the ecological sustainability entrepreneurship literature and future research directions. J. Clean. Prod. 2017, 147, 44-56. [CrossRef]

57. Keskin, D.; Diehl, J.C.; Molenaar, N. Innovation process of new ventures driven by sustainability. J. Clean. Prod. 2013, 45, 50-60. [CrossRef]

58. Schaltegger, S.; Wagner, M. Sustainable entrepreneurship and sustainability innovation: Categories and interactions. Bus. Strat. Environ. 2011, 20. [CrossRef]

59. Khanna, M.; Deltas, G.; Harrington, D.R. Adoption of pollution prevention techniques: The role of management systems and regulatory pressures. Environ. Resour. Econ. 2009, 44, 85-106. [CrossRef]

60. Santini, C. Ecopreneurship and Ecopreneurs: Limits, trends and characteristics. Sustainability 2017, 9, 492. [CrossRef]

61. Plouffe, S.; Lanoie, P.; Berneman, C.; Vernier, M.F. Economic benefits tied to ecodesign. J. Clean. Prod. 2011, 19, 573-579. [CrossRef] 
62. Deutz, P.; McGuire, M.; Neighbour, G. Eco-design practice in the context of a structured design process: An interdisciplinary empirical study of UK manufacturers. J. Clean. Prod. 2013, 39, 117-128. [CrossRef]

63. López, F.J.D.; Montalvo, C. A comprehensive review of the evolving and cumulative nature of eco-innovation in the chemical industry. J. Clean. Prod. 2015, 102, 30-43. [CrossRef]

64. Liao, Y.C.; Tsai, K.H. Innovation intensity, creativity enhancement, and eco-innovation strategy: The roles of customer demand and environmental regulation. Bus. Strat. Environ. 2019, 28, 316-326. [CrossRef]

65. Demirel, P.; Kesidou, E. Sustainability-oriented capabilities for eco-innovation: Meeting the regulatory, technology, and market demands. Bus. Strat. Environ. 2019, 28, 847-857. [CrossRef]

66. Senivongse, C.; Bennet, A.; Mariano, S. Clarifying absorptive capacity and dynamic capabilities dilemma in high dynamic market IT SMEs. VINE J. Inf. Knowl. Manag. Syst. 2019, 49, 372-396. [CrossRef]

67. Katkalo, V.S.; Pitelis, C.N.; Teece, D.J. Introduction: On the nature and scope of dynamic capabilities. Ind. Corp. Chang. 2010, 19, 1175-1186. [CrossRef]

68. Teece, D.J. A dynamic capabilities-based entrepreneurial theory of the multinational enterprise. J. Int. Bus. Stud. 2014, 45, 8-37. [CrossRef]

69. Wu, L.Y. Applicability of the resource-based and dynamic-capability views under environmental volatility. J. Bus. Res. 2010, 63, 27-31. [CrossRef]

70. Wójcik, P. Exploring Links Between Dynamic Capabilities Perspective and Resource-Based View: A Literature Overview. Int. J. Manag. Econ. 2015, 45, 83-107. [CrossRef]

71. Wang, Y.; Sun, X.; Guo, X. Environmental regulation and green productivity growth: Empirical evidence on the Porter Hypothesis from OECD industrial sectors. Energy Policy 2019, 132, 611-619. [CrossRef]

72. Köhler, A.R. Challenges for eco-design of emerging technologies: The case of electronic textiles. Mater. Des. 2013, 51, 51-60. [CrossRef]

73. Ravi, V. Analysis of interactions among barriers of eco-efficiency in electronics packaging industry. J. Clean. Prod. 2015, 101, 16-25. [CrossRef]

74. Utting, P. Business Responsibility for Sustainable Development; UNRISD: Geneva, Switzerland, 2000.

75. Thomas, V.M.; Graedel, T.E. Research issues in sustainable consumption: Toward an analytical framework for materials and the environment. Environ. Sci. Technol. 2003, 37, 5383-5388. [CrossRef]

76. Paek, B.; Lee, H. Strategic entrepreneurship and competitive advantage of established firms: Evidence from the digital TV industry. Int. Entrep. Manag. J. 2018, 14, 883-925. [CrossRef]

77. Teunissen, K.; De Olde, L.J. EcoDesign for TV displays. Inf. Disp. 2010, 26, 10-14. [CrossRef]

78. Renteria, A.; Alvarez, E.; Perez, J.; Del Pozo, D. A methodology to optimize the recycling process of WEEE: Case of television sets and monitors. Int. J. Adv. Manuf. Technol. 2011, 54, 789-800. [CrossRef]

79. Powell, K.R.; Peterson, S.R. Coverage and quality: A comparison of Web of Science and Scopus databases for reporting faculty nursing publication metrics. Nurs. Outlook 2017, 65, 572-578. [CrossRef]

80. Paek, B.; Kim, J.; Park, J.; Lee, H. Outsourcing strategies of established firms and sustainable competitiveness: Medical device firms. Sustainability 2019, 11, 4550. [CrossRef]

81. Moon, S.; Lee, H. The role of standards-related capacity building on the sustainable development of developing countries: Focusing on the Korea's standards-related AfT case in Bolivia. Sustainability 2020, 12, 5199. [CrossRef]

82. Krippendor, K. Content Analysis: An Introduction to Its Methodology, 2nd ed.; Sage Publications: Thousand Oaks, CA, USA, 2004; ISBN 0761915443.

83. Elo, S.; Kyngäs, H. The qualitative content analysis process. J. Adv. Nurs. 2008, 62, 107-115. [CrossRef]

84. Hsieh, H.F.; Shannon, S.E. Three approaches to qualitative content analysis. Qual. Health Res. 2005, 15, 1277-1288. [CrossRef] [PubMed]

85. Saldaña, J. The Coding Manual for Qualitative Researchers; Sage Publications: Thousand Oaks, CA, USA, 2009.

86. Bevington, G.; Wolcott, H.F. Transforming Qualitative Data: Description, Analysis, and Interpretation. Mod. Lang. J. 1996, 80. [CrossRef]

87. Eriksson, T. Processes, antecedents and outcomes of dynamic capabilities. Scand. J. Manag. 2014, 30, 65-82. [CrossRef]

88. Ambrosini, V.; Bowman, C. What are dynamic capabilities and are they a useful construct in strategic management? Int. J. Manag. Rev. 2009, 11, 29-49. [CrossRef]

89. Eisenhardt, K.M.; Martin, J.A. Dynamic capabilities: What are they? Strat. Manag. J. 2000, 21, 1105-1121. [CrossRef]

90. McGrath, R.G. The End of Competitive Advantage: How to Keep Your Strategy Moving as Fast as Your Business, 1st ed.; Harvard Business Review Press: Boston, MA, USA, 2013.

91. Leitner, A.; Wehrmeyer, W.; France, C. The impact of regulation and policy on radical eco-innovation: The need for a new understanding. Manag. Res. Rev. 2010, 33, 1022-1041. [CrossRef]

92. Hojnik, J.; Ruzzier, M. What drives eco-innovation? A review of an emerging literature. Environ. Innov. Soc. Transit. 2016, 19, 31-41. [CrossRef]

93. Van Hemel, C.; Cramer, J. Barriers and stimuli for ecodesign in SMEs. J. Clean. Prod. 2002, 10, 439-453. [CrossRef]

94. Cicconi, P.; Landi, D.; Russo, A.C.; Nardelli, M.; Raffaeli, R.; Germani, M. A CSP-based design framework for appliances under energy labelling. Int. J. Interact. Des. Manuf. 2018, 12, 1243-1263. [CrossRef] 
95. Kijek, T. Modelling of eco-innovation diffusion: The EU eco-label. Comp. Econ. Res. 2015, 18, 65-79. [CrossRef]

96. Priem, R.L. A consumer perspective on value creation. Acad. Manag. Rev. 2007, 32, 219-235. [CrossRef]

97. Teece, D.J. Explicating dynamic capabilities: The nature and microfoundations of (sustainable) enterprise performance. Strat. Manag. J. 2007, 28, 1319-1350. [CrossRef]

98. Čirjevskis, A. The role of dynamic capabilities as drivers of business model innovation in mergers and acquisitions of technologyadvanced firms. J. Open Innov. Technol. Mark. Complex. 2019, 5, 12. [CrossRef]

99. Wang, C.L.; Ahmed, P.K. Dynamic capabilities: A review and research agenda. Int. J. Manag. Rev. 2007, 9, 31-51. [CrossRef]

100. Zahra, S.A.; George, G. Absorptive capacity: A review, reconceptualization, and extension. Acad. Manag. Rev. 2002, 27, 185-203. [CrossRef]

101. Wang, C.L.; Ahmed, P.K. The development and validation of the organisational innovativeness construct using confirmatory factor analysis. Eur. J. Innov. Manag. 2004, 7, 303-313. [CrossRef]

102. Gibbs, D. Sustainability entrepreneurs, ecopreneurs and the development of a sustainable economy. Greener Manag. Int. 2006, 55, 63-78. [CrossRef]

103. Bartlett, D. Eco-innovation. In Encyclopedia of Corporate Social Responsibility, 1st ed.; Idowu, S.O., Capaldi, N., Zu, L., Das Gupta, A., Eds.; Springer: New York, NY, USA, 2013; pp. 865-870.

104. Isaak, R. The making of the ecopreneur. In Making Ecopreneurs: Developing Sustainable Entrepreneurship, 2nd ed.; Schaper, M., Ed.; Gower Publishing: Farnham, UK, 2010; pp. 52-63.

105. Kiefer, C.P.; Carrillo-Hermosilla, J.; Del Río, P. A taxonomy of eco-innovation types in firms. Documentos Trabajo 2018, 1, 1-30.

106. Prendeville, S.; O'Connor, F.; Palmer, L. Material selection for eco-innovation: SPICE model. J. Clean. Prod. 2014, 85, 31-40. [CrossRef]

107. Ceschin, F.; Gaziulusoy, I. Evolution of design for sustainability: From product design to design for system innovations and transitions. Des. Stud. 2016, 47, 118-163. [CrossRef]

108. Bakker, C.; Wang, F.; Huisman, J.; den Hollander, M. Products that go round: Exploring product life extension through design. J. Clean. Prod. 2014, 69, 10-16. [CrossRef]

109. Rousseaux, P.; Gremy-Gros, C.; Bonnin, M.; Henriel-Ricordel, C.; Bernard, P.; Floury, L.; Staigre, G.; Vincent, P. “Eco-tool-seeker": A new and unique business guide for choosing ecodesign tools. J. Clean. Prod. 2017, 151, 546-577. [CrossRef] 